\title{
Quality characterization and pollution source identification of surface water using multivariate statistical techniques, Nalagarh Valley, Himachal Pradesh, India
}

\author{
Rajkumar Herojeet $^{1}$ (D) Madhuri S. Rishi $^{2} \cdot$ Renu Lata $^{3} \cdot$ Konchok Dolma $^{4}$
}

Received: 30 December 2014 / Accepted: 20 July 2017/ Published online: 29 July 2017

(c) The Author(s) 2017. This article is an open access publication

\begin{abstract}
Sirsa River flows through the central part of the Nalagarh valley, belongs to the rapid industrial belt of Baddi, Barotiwala and Nalagarh (BBN). The appraisal of surface water quality to ascertain its utility in such ecologically sensitive areas is need of the hour. The present study envisages the application of multivariate analysis, water utility class and conventional graphical representation to reveal the hidden factor responsible for deterioration of water quality and determine the hydrochemical facies and its evolution processes of water types in Nalagarh valley, India. The quality assessment is made by estimating $\mathrm{pH}$, electrical conductivity (EC), total dissolved solids (TDS), total hardness, major ions $\left(\mathrm{Na}^{+}, \mathrm{K}^{+}, \mathrm{Ca}^{2+}, \mathrm{Mg}^{2+}\right.$, $\mathrm{HCO}_{3}{ }^{-}, \mathrm{Cl}^{-}, \mathrm{SO}_{4}{ }^{2-}, \mathrm{NO}_{3}{ }^{-}$and $\mathrm{PO}_{4}{ }^{3-}$ ), dissolved oxygen (DO), biological oxygen demand (BOD) and total coliform (TC) to determine its suitability for drinking and domestic purposes. The parameters like $\mathrm{pH}, \mathrm{TDS}, \mathrm{TH}, \mathrm{Ca}^{2+}$, $\mathrm{HCO}_{3}{ }^{-}, \mathrm{Cl}^{-}, \mathrm{SO}_{4}{ }^{2-}, \mathrm{NO}_{3}{ }^{-}$are within the desirable limit as per Bureau of Indian Standards (Indian Standard Drinking Water Specification (Second Edition) IS:10500. Indian Standard Institute, New Delhi, pp 1-18, 2012). $\mathrm{Mg}^{2+}, \mathrm{Na}^{+}$ and $\mathrm{K}^{+}$ions for pre monsoon and $\mathrm{EC}$ during pre and post monsoon at few sites and approx $40 \%$ samples of BOD and TC for both seasons exceeds the permissible limits indicate
\end{abstract}

Rajkumar Herojeet

herojeet.rk@gmail.com

1 Department of Environment Studies, Post Graduate Government College, Chandigarh, India

2 Department of Environment Studies, Panjab University, Chandigarh, India

3 Pant National Institute of Himalayan Environment \& Sustainable Development, Mohal, Himachal Pradesh, India

4 E.J.M. College, Leh, India organic contamination from human activities. Water quality classification for designated use indicates that maximum surface water samples are not suitable for drinking water source without conventional treatment. The result of piper trillinear and Chadha's diagram classified majority of surface water samples for both seasons fall in the fields of $\mathrm{Ca}^{2+}-\mathrm{Mg}^{2+}-\mathrm{HCO}_{3}{ }^{-}$water type indicating temporary hardness. PCA and CA reveal that the surface water chemistry is influenced by natural factors such as weathering of minerals, ion exchange processes and anthropogenic factors. Thus, the present paper illustrates the importance of multivariate techniques for reliable quality characterization of surface water quality to develop effective pollution reduction strategies and maintain a fine balance between the industrialization and ecological integrity.

Keywords Industrial effluent - Surface water - Sirsa River . Hydrochemical facies - Principal component analysis .

Cluster analysis

\section{Introduction}

Surface water is one of the most precious inland resources, necessary to sustain life, agricultural, industrial and recreational purposes (Razmkhah et al. 2010; Biglin and Konanc 2016). The quality of a river at any point reflects major influences, including the lithology of the basin, atmospheric inputs, climatic conditions and anthropogenic inputs (Bricker and Jones 1995; Reza and Singh 2010; Herojeet et al. 2015b; Jung et al. 2016). On the other hand, rivers play a major role in assimilation or transporting multitude of pollutants present in municipal and industrial wastewater and runoff from agricultural land (Qadir et al. 
2008; Wang et al. 2013; Malik and Hashmi 2017). Municipal and industrial wastewater discharge constitutes a constant polluting source, whereas surface runoff is a seasonal phenomenon, largely influenced by climate within the basin (Singh et al. 2004; Kumar et al. 2015; Bhutiani et al. 2016). Seasonal variations in precipitation, surface runoff, interflow, groundwater flow and pumped in and outflows have a strong effect on river discharge and, subsequently, on the concentration of pollutants in river water (Vega et al. 1998). River water pollution is a major global concern [United Nation Environment Programme (UNEP) 2000; Bhutiani et al. 2016] and threat to aquatic ecosystems as stated in the Ministerial declaration of the 2nd World Water Forum (2000). Though industrialization acted as engines of economic development, it deteriorates the air, water, soil resources and biodiversity (Kannj and Achi 2011; Odumosu 1992; Hossain et al. 2012). Developing country like India experiences water pollution problems due to changing lifestyles, economic enhancement, urban sprawl and landuse pattern (Vipan et al. 2013; Herojeet et al. 2015a). In India, industrial effluents both untreated/partially treated wastewaters often get mixed with domestic sewage contaminated the surface water body affecting homeostasis of riverine ecosystem.

Water chemistry is controlled by various hidden factors related to natural and anthropogenic influences that is difficult to understand and unable to interpret meaningful information (Zhao et al. 2012; Isah et al. 2013; Ismail et al. 2014; Sum and Gui 2015; Herojeet et al. 2016). Such limitations can be overcome by the application of multivariate statistical approach (Singh et al. 2014; Hamid et al. 2016; Herojeet et al. 2016). The application of different multivariate statistical techniques, such as cluster analysis (CA) and principal component analysis (PCA) helps in the interpretation of complex data matrices for better understanding of water quality and its ecological status and allows the identification of possible factors that influence drainage watershed (Vega et al. 1998; Lee et al. 2001; Adams et al. 2001; Wunderlin et al. 2001; Reghunath et al. 2002; Simeonov et al. 2003, 2004). Multivariate statistical techniques are considered trustworthy and authentic approaches to characterize and evaluate surface water quality for efficient management and effective solution to pollution problems (Helena et al. 2000; Singh et al. 2004, 2005; Papazova and Simeonova 2012, 2013; Okiongbo and Douglas 2015; Hamid et al. 2016, Le et al. 2017). Noori et al. (2012) suggested that PCA and CA techniques are useful tools for identifying the importance of water quality monitoring stations.

Nalagarh valley represents a portion of the southernmost expanse of Solan district, belongs to the rapid industrial belt of Baddi, Barotiwala and Nalagarh (BBN) region. The valley has been rated as fastest industrial growth in the last decade owing to incentives granted by the Government which act as a catalyst in boosting industrial development in the state, particularly in the BBN area (Herojeet et al. 2013a; Kamaldeep et al. 2011). Large- and small-scale industrial development along with urbanization has taken place randomly along the Sirsa watershed resulted to high industrial as well as domestic load in the Sirsa river. Several industries from the far flunk States too have shifted to Nalagarh valley to reap benefits of these incentives (GoHP 2011). Even many industrial units $(\sim 55 \%)$ are operating without proper legal licenses (Anonymous 2014). As per a report prepared by the BBN Authority in 2007, around $72 \%$ of the industries in Nalagarh are processing without effluent treatment plants (ETP). This has further aggravated the pollution menace in surface water and groundwater in the valley (Kamaldeep et al. 2011). Conversion of agricultural land to non-agricultural land, often illegally, for various industrial activities are a common scenario that has led to various environmental problems including pollution of the water resources (GoI 2012). Therefore, the fundamental understandings of hydro-morphological, chemical and biological characteristics are important aspect for virtual and long-term management of surface water (Muangthong and Shrestha 2015). An effective monitoring program is necessary that includes large and complex physicochemical parameters to draw meaningful information of surface water quality related to spatial and temporal variations (Shrestha and Kazama 2007; Guangjia et al. 2010; Muangthong 2015). However, analysis of large datasets of measured parameters is complex; hence, it requires mutliassessment techniques including classification, modeling and interpretations of numerous data matrix due to rich information contain about the water resources (Iscen et al. 2008; Boyacioglu 2006).

From our knowledge, no such study has carried out to assess the impact of rapid industrial development on Sirsa river. The main aim of the study is to examine the dominant ions influencing the water types and the major factors affecting the water quality parameters using multivariate techniques. The results of this study will help proper management of valuable water resources and maintain a balance between the industrial development and environment purity.

\section{Study area}

Nalagarh valley forms a South-Eastern narrow prolongation of a great outermost Himalayan intermountain valley area of about $230 \mathrm{sq}$. km. It lies between Northern latitudes of $30^{\circ} 52^{\prime}-31^{\circ} 04^{\prime}$ and Eastern longitudes of $76^{\circ} 40^{\prime}-76^{\circ} 55^{\prime}$. The valley is having common border with Haryana towards 


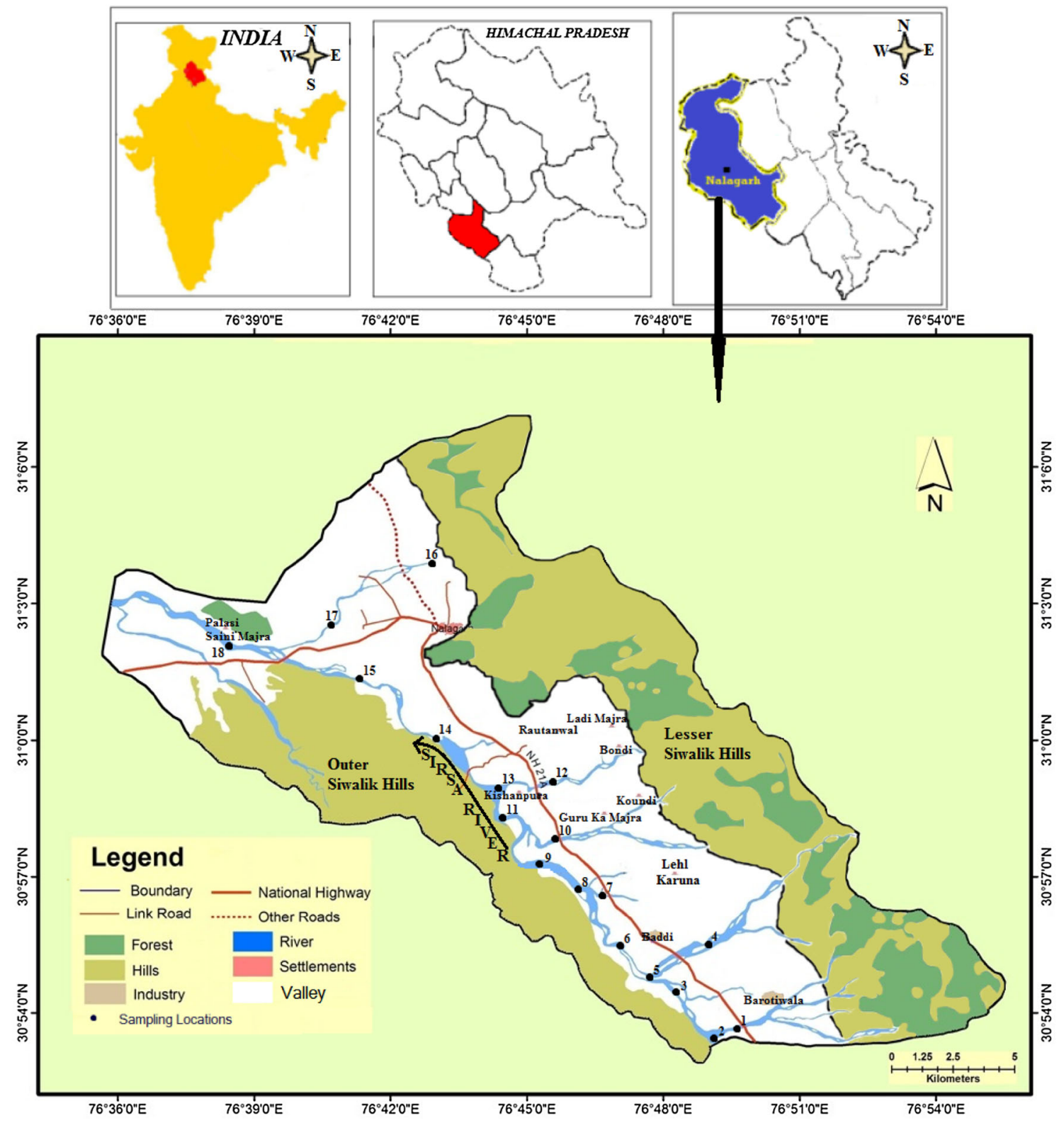

Fig. 1 Map showing sampling points in the study area

south-east, i.e., Kalka-Pinjor area and with Punjab towards south-west, i.e., Ropar district. Sirsa river is perennial river which flows southwesterly in the area and joins Sutlej $10 \mathrm{kms}$ upstream of Ropar (Fig. 1). There are numerous perennial and ephemeral streams emerging from the northeast (NE) flank passing through industrial belt often loaded with industrial and sewage discharges and transverse flow across the valley to join Sirsa nadi (CGWB 1975). The important streams among them are Chikni nadi, Phula nadi, Ratta nadi, Balad nadi and Surajpur chao. The discharge in the streams fluctuates in accordance with the climatic conditions. During the monsoon, the streams are flooded and carry enormous load of sediment and deposited them in the flood plain of the valley.

\section{Geology}

The geology of the area is complex not from the stratigraphical point of view but for its tectonic complexities (Khan 1988). Stratigraphically, the Nalagarh valley and its flanks are bounded by the tertiary formations and structurally they are highly disturbed. The rock types of the area can be broadly grouped into two tectonic zones striking and trending NW-SE direction. So, the direction of their tectonic zones position from North to South is as follows (Fig. 2);

(a) Belt of lower and middle tertiary occurring along the NE flank of the valley (Para-autochthonous). 
Fig. 2 Geological map of the study area (Source: Dash et al. 2013)

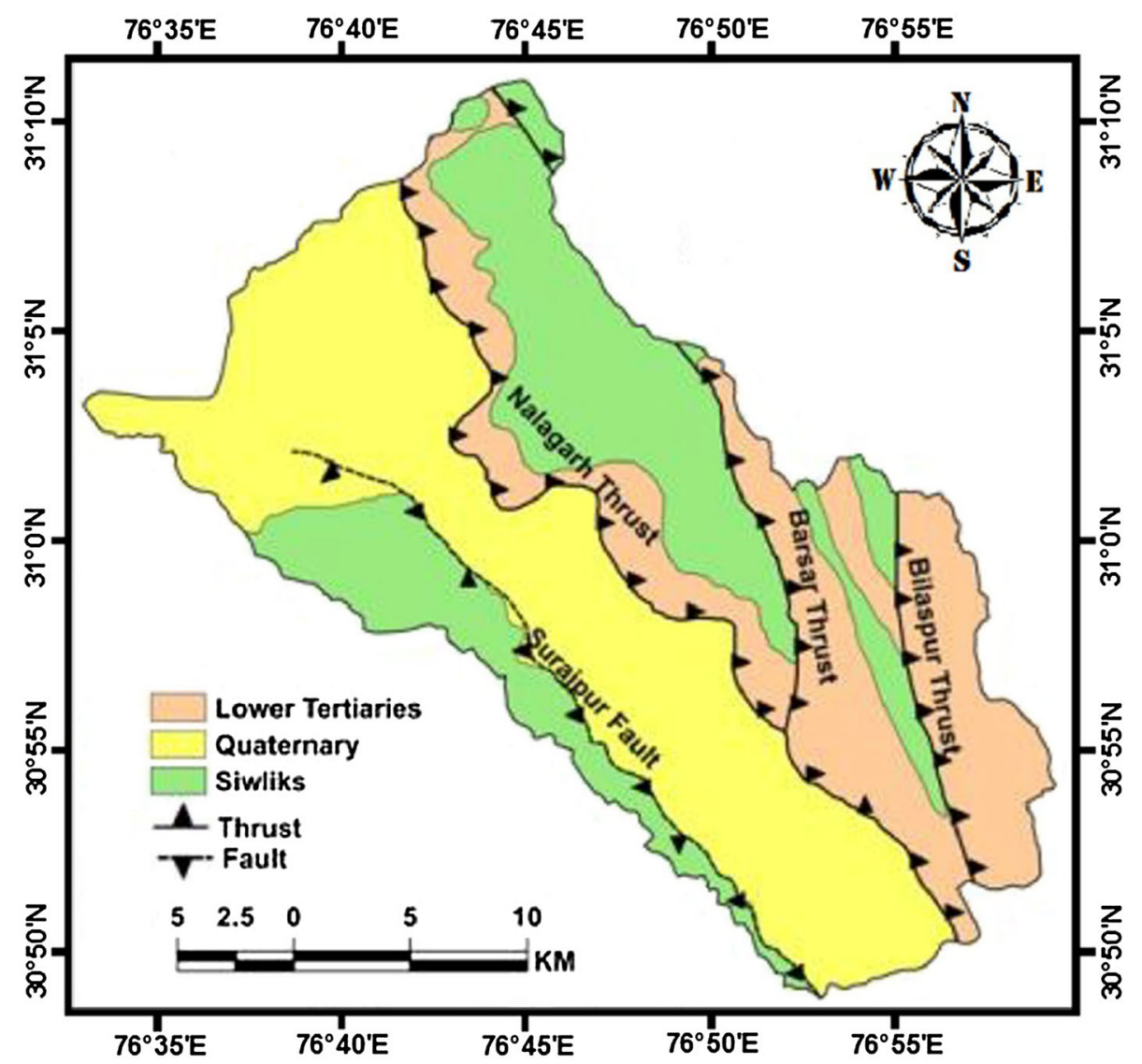

(b) Belt of upper tertiary confined to the valley and along its SW flank (Autochthonous). The contact of these zones is marked by a major fault (Nalagarh thrust).

Tectonically, the area is highly disturbed, two major thrust trending NE-SW are Nalagarh and Sirsa thrusts. Nalagarh thrust is formed between Kasauli and middle Siwaliks whereas Sirsa thrust separates upper and middle Siwaliks. The Sirsa River flows along a fault line, called Surajpur Fault (Khan 1970). The major part of the Sirsa river basin is covered by alluvium soil with Holocene and Pre-Holocene deposits. The alluvium soil varies from 10 to $20 \mathrm{~cm}$ thickness and is mostly granular. The upper and middle parts of the river basin are predominated by alternate beds of clay and cobbles, pebbles, gravel, sand. The sediments get finer and finer till it become clay in the downstream part of basin. The stratigraphical sequence of the basin is given in Table 1 .

\section{Materials and methods}

\section{Sampling and laboratory analysis}

12 samples were collected along the Sirsa River and 6 samples from the tributaries flowing around the industrial region to appraise the surface water quality during per monsoon (May
2012) and post monsoon (October 2012) seasons (Fig. 1). Water sample were collected on HDP $(1000 \mathrm{~mL})$ plastic bottles. At the time of sampling, the bottles were thoroughly rinsed two to three times with the water to be sampled. $\mathrm{pH}$, electrical conductivity and total dissolved solids were measured on the spot of sample collection by portable water and soil analysis kit. For major cations analysis samples were filtered through using Whatman filter paper no. 42 of diameter $125 \mathrm{~mm}$ and pore size $2.5 \mathrm{~lm}$ and preserved by acidifying to $\mathrm{pH} \sim 2$ with $\mathrm{HNO}_{3}$ and kept at a temperature of $4{ }^{\circ} \mathrm{C}$ until

Table 1 Geological succession of the study area

\begin{tabular}{lll}
\hline Rocks & Lithology & Age \\
\hline Holocene deposits & $\begin{array}{c}\text { Modern alluvium and river } \\
\text { sediments }\end{array}$ & Recent \\
$\begin{array}{l}\text { Pre-holocene } \\
\text { deposits }\end{array}$ & River terrace & Upper \\
Upper siwaliks & $\begin{array}{c}\text { Boulder conglomerates, } \\
\text { Sand rocks and clays }\end{array}$ & $\begin{array}{c}\text { Lower } \\
\text { pleistocene }\end{array}$ \\
Middle siwaliks & $\begin{array}{c}\text { Sandstones, clays and } \\
\text { conglomerates }\end{array}$ & $\begin{array}{c}\text { Pleistocene } \\
\text { Lower siwaliks }\end{array}$ \\
& $\begin{array}{c}\text { Gray sandstones and purple } \\
\text { clays }\end{array}$ & Upper miocene \\
Kasauli series & $\begin{array}{c}\text { Purple, gray sandstones and } \\
\text { purple clays and shales }\end{array}$ & Lower miocene \\
& &
\end{tabular}


Table 2 Summarized water quality parameters along with their abbreviations, units and analytical methods used

\begin{tabular}{|c|c|c|c|}
\hline Parameters & Abbreviations & Units & Analytical methods \\
\hline $\mathrm{pH}$ & $\mathrm{pH}$ & $\mathrm{pH}$ unit & $\mathrm{pH}$ meter \\
\hline Electrical conductivity & $\mathrm{EC}$ & $\mu \mathrm{S} / \mathrm{cm}$ & Electronic India, Model-161 \\
\hline Total dissolved solids & TDS & $\mathrm{mg} / \mathrm{L}$ & Electronic India, Model-161/indirect method $(\mathrm{TDS}=\mathrm{EC} \times 0.65)$ \\
\hline Total hardness & TH & $\mathrm{mg} / \mathrm{L}$ & Titration with EDTA using Eriochrome Black T as indicator \\
\hline Calcium & $\mathrm{Ca}^{2+}$ & $\mathrm{mg} / \mathrm{L}$ & Titration with EDTA using Murexide as indicator \\
\hline Magnesium & $\mathrm{Mg}^{2+}$ & $\mathrm{mg} / \mathrm{L}$ & Titration with EDTA as titrant and eriochrome black $\mathrm{T}$ as indicator) \\
\hline Sodium & $\mathrm{Na}^{+}$ & $\mathrm{mg} / \mathrm{L}$ & Flame photometer \\
\hline Potassium & $\mathrm{K}^{+}$ & $\mathrm{mg} / \mathrm{L}$ & Flame photometer \\
\hline Bicarbonate & $\mathrm{HCO}_{3}^{-}$ & $\mathrm{mg} / \mathrm{L}$ & $\begin{array}{l}\text { Titration method using standard } \mathrm{H}_{2} \mathrm{SO}_{4} \text { with phenolphthalein } \\
\text { and methyl orange as an indicator }\end{array}$ \\
\hline Chloride & $\mathrm{Cl}^{-}$ & $\mathrm{mg} / \mathrm{L}$ & Titration with $\mathrm{AgNO}_{3}$ using potassium dichromate as indicator \\
\hline Nitrate & $\mathrm{NO}_{3}^{-}$ & $\mathrm{mg} / \mathrm{L}$ & Spectrophotometer (using phenol disulfonic acid) \\
\hline Sulfate & $\mathrm{SO}_{4}{ }^{2-}$ & $\mathrm{mg} / \mathrm{L}$ & Spectrophotometer (using $\mathrm{BaCl}_{2}$ as conditioning agent) \\
\hline Phosphate & $\mathrm{PO}_{4}{ }^{2-}$ & $\mathrm{mg} / \mathrm{L}$ & Spectrophotometer (using stannous chloride) \\
\hline Dissolved Oxygen & DO & $\mathrm{mg} / \mathrm{L}$ & Winkler's Azide method at $20^{\circ} \mathrm{C}$ ( 5 days) \\
\hline Biological oxygen demand & BOD & $\mathrm{mg} / \mathrm{L}$ & Winkler's Azide method \\
\hline Total coliform & $\mathrm{TC}$ & MPN/100 mL & Multiple tube fermentation techniques \\
\hline
\end{tabular}

analysis. Chemical analysis of major cations $\left(\mathrm{Na}^{+}, \mathrm{K}^{+}, \mathrm{Ca}^{2+}\right.$, $\left.\mathrm{Mg}^{2+}\right)$, major anions $\left(\mathrm{SO}_{4}{ }^{2-}, \mathrm{Cl}^{-}, \mathrm{HCO}_{3}{ }^{-}\right.$and $\left.\mathrm{NO}_{3}{ }^{2-}\right), \mathrm{DO}$, $\mathrm{BOD}_{5}$ and $\mathrm{TC}$ were determined according to the standard methods for the examination of water and wastewater (APHA, AWWA, WEF 2005). The different water quality parameters, their units and methods of analysis are summarized in Table 2. The analytical data quality was ensured through careful standardization, procedural blank measurements and duplicate samples. The ionic charge balance of each sample was within $\pm 5 \%$. Maps were prepared using Mapinfo 6.5 and Vertical Mapper 3.0 and Piper trillinear diagram were plotted using RockWorks 15. A Microsoft Excel 2007 is employed for the calculations and data analysis.

\section{Multivariate statistical analysis}

Multivariate statistical techniques have been applied by many researchers to assess and characterize freshwater, marine water and sediment quality (Noori et al. 2010; Muangthong and Shrestha 2015; Hamid et al. 2016; Jung et al. 2016). Principal component analysis (PCA) and cluster analysis (CA) are employed with the objective to group the similar sampling locations based on water quality characteristics and identify the pollution sources influencing the water chemistry. Both PCA and CA are analyzed using statistical software Minitab 16, respectively.

\section{Principal component analysis (PCA)}

Principal component analysis (PCA) is one of the best multivariate statistical techniques for extracting linear relationship among a set of variables (Simeonov et al. 2003). PCA is an analytical technique whereby a complex data set containing variables is transformed to a smaller set of new variables, which maximize the variance of the original data set. PCA provides information on the significant parameters with minimum loss of original information (Singh et al. 2004; Helena et al. 2000). This is achieved by transforming to a new set of variables which are uncorrelated, and which are ordered so that the first few retain most of the variation present in all of the original variables. Therefore, standardization ( $z$ scale) was made on each chemical parameter prior to statistical analysis to eliminate biasness by any parameter of different units with high concentration and renders the data dimensionless (Simeonov et al. 2004). The principal components are generated in a sequentially ordered manner with decreasing contributions to the variance, i.e., the first principal component (PC1) explains most of the variations present in the original data, and successive principal components account for decreasing proportions of the variance (Pires et al. 2009; Vieira et al. 2012). Liu et al. (2003) classified the factor loadings as "strong", "moderate" and "weak", corresponding to absolute loading values of $>0.75$, $0.75-0.50$ and $0.50-0.30$, respectively.

\section{Cluster analysis (CA)}

Cluster analysis (hierarchical clustering), on the other hand, is a useful method of objectively organizing a large data set into groups on the basis of a given set of characteristics. The primary objective of CA is to identify relatively homogenous groups or clusters of objects based on 
their similarities/dissimilarities (Wai et al. 2010). The grouping of similar objects occurs first and eventually, as the similarity decreases, all subgroups are merged into a single cluster. This can ultimately assist in the recognition of potentially meaningful patterns (Swanson et al. 2001). Cluster analysis (CA) is performed on the standardized data set ( $z$-transformation) by means of the Ward's method using squared Euclidean distance as a measure of similarity to obtain dendrogram (Otto 1998). The seasonal variability of water quality sampling locations is determined from CA, using the linkage distance, reported as $\left(D_{\text {link }} / D_{\max }\right) \times 100$, which represents the quotient between the linkage distances for a particular case divided by the maximal linkage distance. The quotient is then multiplied by 100 as a way to standardize the linkage distance represented on the $y$-axis (Wunderlin et al. 2001; Simeonov et al. 2003; Singh et al. 2004, 2005).

\section{Results and discussion}

Physicochemical and biological compositions of surface water samples are presented in Tables 3 and 4. Table 5 provides the statistical description of water quality parameters that include range, mean and standard deviation and also calculates the percentage of water samples that exceed the prescribed desirable and permissible limits of the Bureau of Indian Standards (BIS 2012) and World Health Organization (WHO 2011) for drinking water. Maximum, minimum and median of the surface water samples for pre monsoon and post monsoon is depicted by box plot (Fig. 3). pH value varied between 7.07 and 7.83 with a mean \pm standard deviation (SD) of $7.53 \pm 0.23$ in pre monsoon season and 7.12-7.62 with a mean \pm SD of $7.38 \pm 0.16$ during post monsoon. The entire water samples are within the prescribed limits of BIS (2012). EC values ranged between 428 and $1570 \mu \mathrm{S} / \mathrm{cm}$ and $429-1512 \mu \mathrm{S} / \mathrm{cm}$ with a mean $\pm \mathrm{SD}$ of $1079.89 \pm 387.56$ and $769.78 \pm 276.26$ during pre and post monsoon. 16.67 and $5.56 \%$ samples are above the permissible limit of 1500 $\mu \mathrm{S} / \mathrm{cm}$ (WHO 2011) indicating temporal variation during the period of investigation. CGWB and CPCB (1999) classified EC values of water for irrigation purpose as given in Table 6. It is observed that 7 and 11 samples during pre monsoon whereas for post monsoon 10 and 8 samples fall in moderate saline to high saline class. Moreover, lower values of EC are recorded in post monsoon due to increasing volume of surface water as rain water causes dilution of effluent. High concentration of TDS in surface water at SW7 (1037 mg/L, pre monsoon) and SW9 (1014 mg/L, post monsoon) is the indicator of excessive anthropogenic activities besides the sampling area (Yisa and Jimoh 2010). The water can be classified based on TDS for irrigation use as Fresh (TDS <1000); Brakish (TDS 1000-10,000); Saline (TDS 10,000-1,000,000) and Brine (TDS >1,000,000) (Todd 1980). Accordingly, majority of the surface water samples fall under fresh for both seasons indicating suitable irrigation purpose. The value of Total Hardness varies from 130 to 476 and 160 to $308 \mathrm{mg} / \mathrm{L}$ with mean $\pm \mathrm{SD}$ of $230.17 \pm 83.08$ and $245.39 \pm 42.71$ for both seasons. Temporal variation is observed in which median value is higher in post monsoon which may be attributed due to the dissolution of calcium and magnesium bearing minerals along with industrial effluent (Herojeet et al. 2013b). As per Durfor and Becker (1964) classification, all the samples come under hard $(66.67 ; 88.89 \%)$ to very hard $(33.33$; $11.11 \%$ ) category during pre and post monsoon (Table 7). Sidhu et al. (2013) have concluded that long-term consumption of extremely hard water is associated with an increase incidence of urolithiasis, anencephaly, some types of cancer and cardiovascular disorders. None of the samples showed TDS and TH values exceeding their permissible limit of 2000 and $600 \mathrm{mg} / \mathrm{L}$ (BIS 2012).

\section{Cations chemistry $\left(\mathrm{Ca}^{2+}, \mathrm{Mg}^{2+}, \mathrm{Na}^{+}, \mathrm{K}^{+}\right)$}

Among the cations, magnesium is the dominant ions suggesting 61.11 and $72.22 \%$ samples are $\mathrm{Mg}^{2+}$-rich water type and remaining $27.78 \%$ indicates no dominant cations (Fig. 4a, b; Table 9) for both seasons. The alkaline earth metals, the concentrations of $\mathrm{Ca}^{2+}$ ranged from 13.46 to 102.61 and 28.6 to $103.45 \mathrm{mg} / \mathrm{L}$ and $\mathrm{Mg}^{2+}$ values varied from 27.00 to 109.37 and 23.85 to $63.78 \mathrm{mg} / \mathrm{L}$ for pre and post monsoon, respectively. Among the alkalies metals, $\mathrm{Na}^{+}$ values varies between $6.6-245.7$ and $11.8-130.0 \mathrm{mg} / \mathrm{L}$ and $\mathrm{K}^{+}$concentrations from 1.3 to 13.8 and 1.4 to $9.0 \mathrm{mg} / \mathrm{L}$ for both seasons. During pre monsoon, 5.56 samples are above the permissible limit of $\mathrm{Mg}^{2+}(100 \mathrm{mg} / \mathrm{L}), \mathrm{Na}^{+}(200 \mathrm{mg} / \mathrm{L})$ and $\mathrm{K}^{+}(12 \mathrm{mg} / \mathrm{L})$, respectively, and none of the sample exceeds permissible limit for post monsoon (BIS 2012). Based on the average concentrations $(\mathrm{mg} / \mathrm{L})$ of all the cations, the ionic dominance in the order of $\mathrm{Na}^{+}(48.55 \%)>\mathrm{Mg}^{2+}(26.38 \%)>\mathrm{Ca}^{2+} \quad$ (21.87) $>\mathrm{K}^{+}$ (3.21) and $\mathrm{Ca}^{2+}(37.73 \%)>\mathrm{Na}^{+}(33.77 \%)>\mathrm{Mg}^{2+}$ $(25.65 \%)>\mathrm{K}^{+}(2.85 \%)$, respectively, for both seasons.

\section{Anion chemistry $\left(\mathrm{HCO}_{3}{ }^{-}, \mathrm{Cl}^{-}, \mathrm{SO}_{4}{ }^{2-}, \mathrm{NO}_{3}{ }^{-}\right.$, $\mathrm{PO}_{4}{ }^{3-}$ )}

The concentrations of $\mathrm{HCO}_{3}{ }^{-}, \mathrm{Cl}^{-}, \mathrm{SO}_{4}{ }^{2-}, \mathrm{NO}_{3}{ }^{-}, \mathrm{PO}_{4}{ }^{3-}$ ranges from 76.0 to $158.0,3.98$ to $40.75,9.82$ to $23.0,0.38$ to $17.89,0.01$ to $0.71 \mathrm{mg} / \mathrm{L}$ for pre monsoon and varies between 92.0 and 164.0, 3.98 and 25.84, 10.52 and 23.0, 0.3 and $18.0,0.01$ and $0.09 \mathrm{mg} / \mathrm{L}$, respectively, during post monsoon season. The anions dominance in the order of 


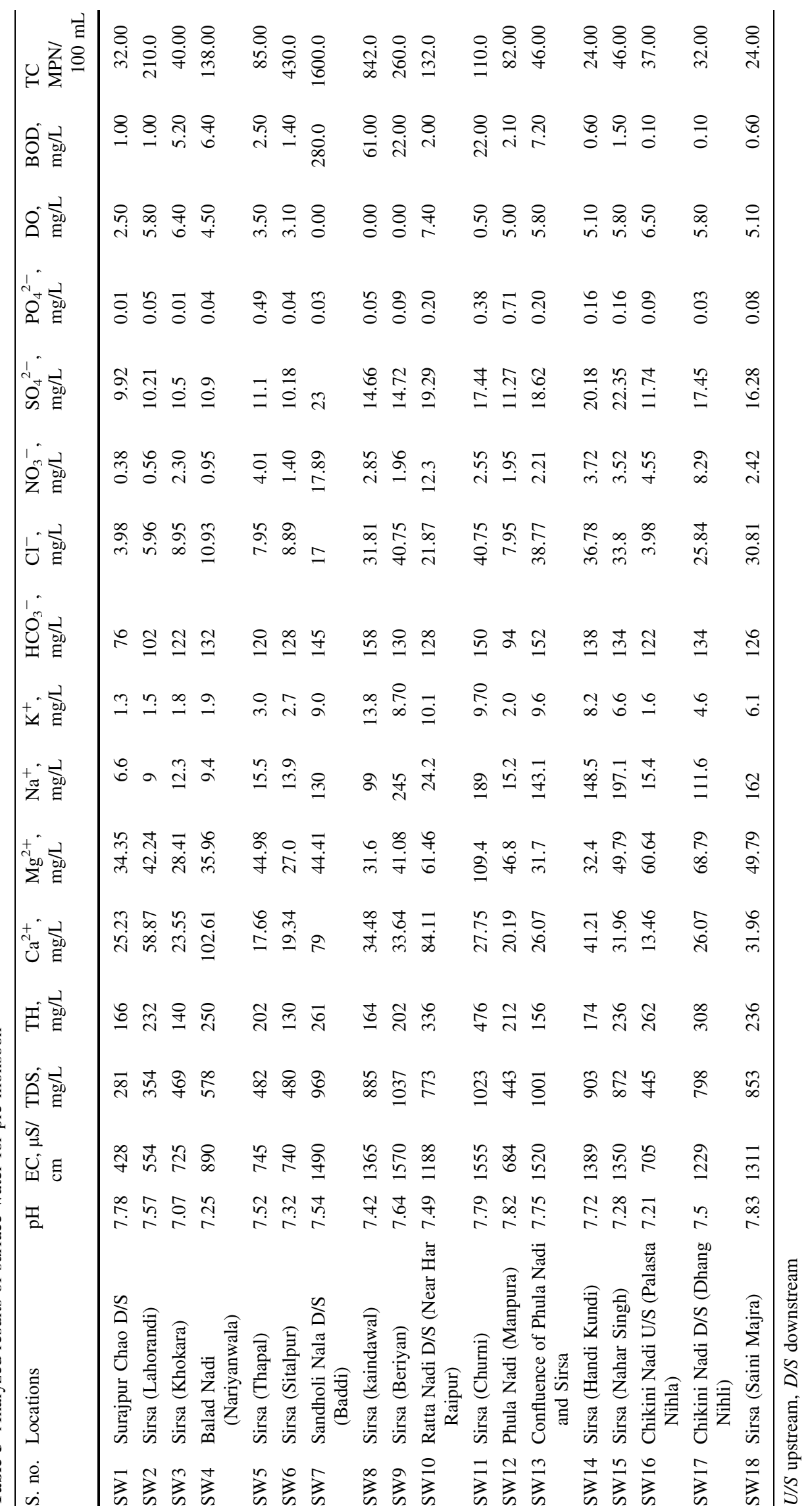




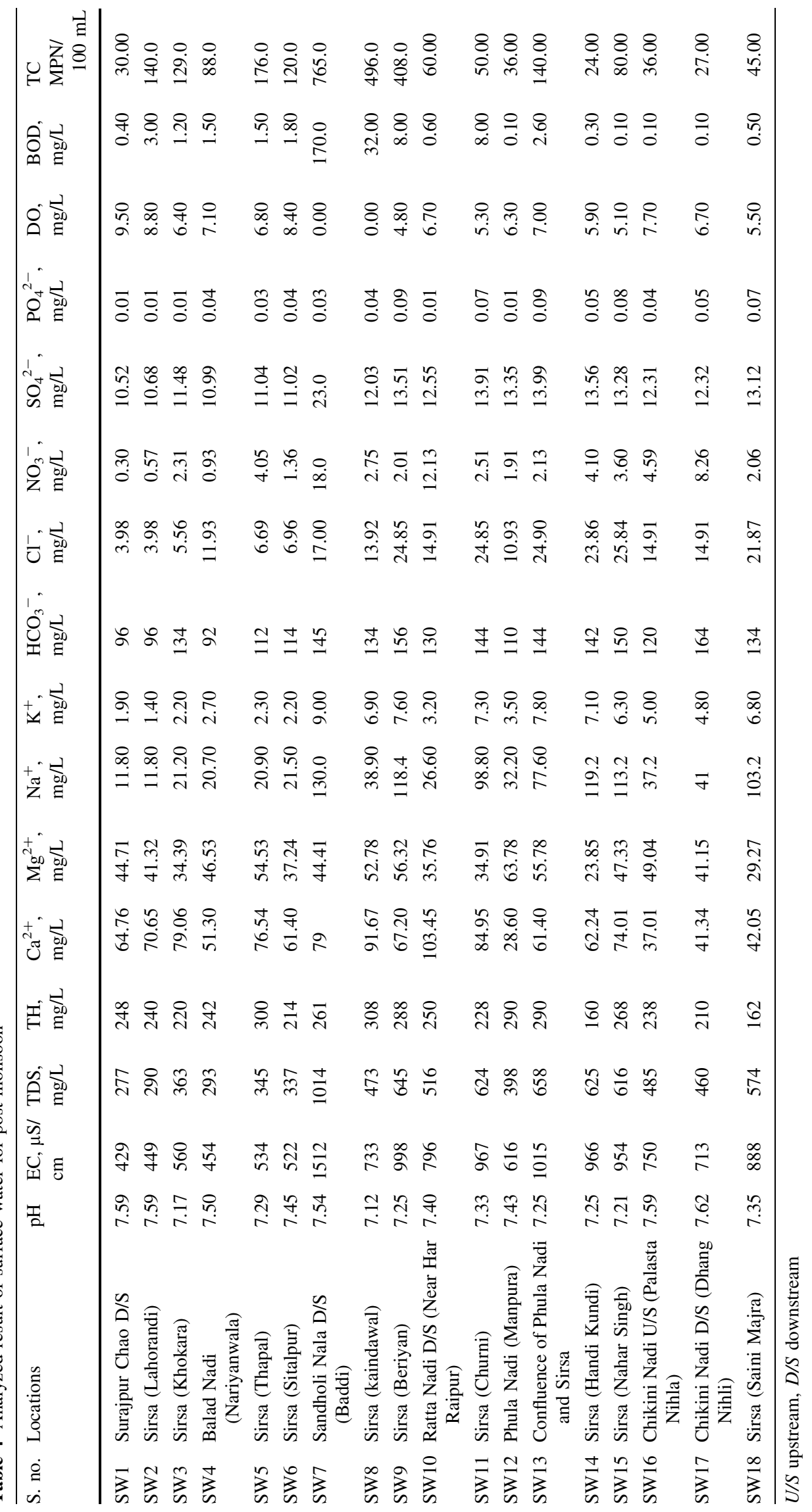




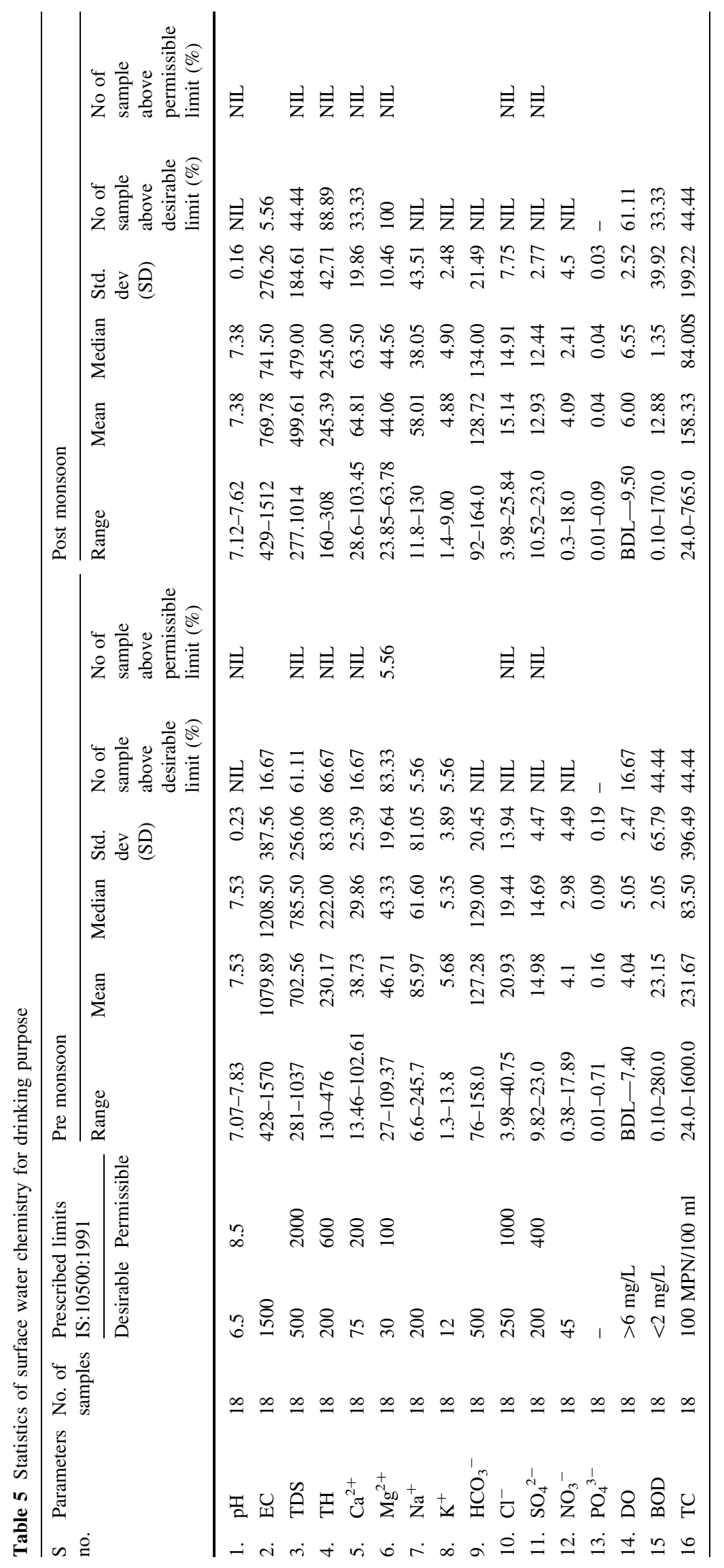



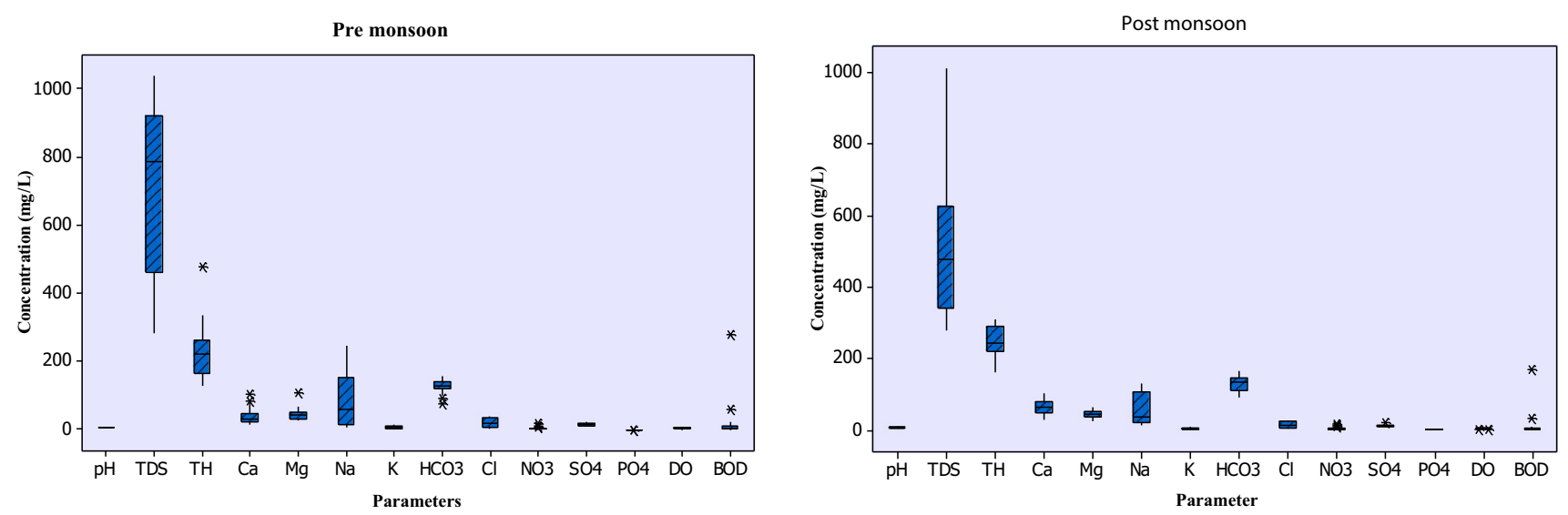

Fig. 3 Box plot of different parameter concentration in the study area (cross outlier, whisker line median, vertical line maximum and minimum and box third and first quartiles)

$\mathrm{HCO}_{3}{ }^{-}>\mathrm{Cl}^{-}>\mathrm{NO}_{3}{ }^{-}>\mathrm{SO}_{4}{ }^{2-}>\mathrm{PO}_{4}{ }^{3-}$ that contribute on an average concentrations $(\mathrm{mg} / \mathrm{L})$ of all the anions for pre monsoon $(76.01,12.50,8.95,2.45$ and $0.09 \%)$ and post monsoon $(79.99,9.41,8.03,2.54$ and $0.03 \%)$, respectively. Among anions, 83.33 and $100 \%$ samples are characterized as $\mathrm{HCO}_{3}{ }^{-}$water indicating the dominant ion for both seasons and $16.67 \%$ samples for pre monsoon plotted near the central zone have no dominant anion (Fig. 4a, b; Table 9). The entire samples of $\mathrm{HCO}_{3}{ }^{-}, \mathrm{Cl}^{-}, \mathrm{SO}_{4}{ }^{2-}$ and $\mathrm{NO}_{3}{ }^{-}$concentrations are well within the permissible limits of 500, 1000, 400 and $45 \mathrm{mg} / \mathrm{L}$ (BIS 2012).

\section{Biological parameters (DO, BOD, TC)}

The content of DO in surface water ranged from BDL (below detectable limit) $-7.40 \mathrm{mg} / \mathrm{L}$ and BDL-9.50 mg/ $\mathrm{L}$ for pre and post monsoon. The DO values fall to zero at SW8 and SW9 during the investigation period depicts not even fit to support aquatic life. DO values $<6$ indicate pollution (WHO 2011), cannot be use for domestic purposes. 16.67 and $61.11 \%$ samples, respectively, are above the permissible limit of $>6 \mathrm{mg} / \mathrm{L}$ (BIS 2012) for both seasons. BOD concentration varies from 0.10 to $280.0 \mathrm{mg} /$ $\mathrm{L}$ during pre monsoon and 0.10 to $170.0 \mathrm{mg} / \mathrm{L}$ for post monsoon. Lower DO and higher BOD are accounted in pre monsoon (Anshu et al. 2011) when river flows are slow and high temperatures increase the organic decomposition discharge from untreated sewage and agricultural runoff. The study area also lacks proper drainage system and modern sanitation facilities where domestic sewage and wastewater directly enter the Sirsa river and its tributaries. TC content in the samples ranged between $24-1600$ and 27-765 MPN/100 mL during pre and post monsoon, respectively. Highest value of TC, BOD and low DO is observed at SW7 for both seasons where Sandholi nala is an effluent channel for sewage and agricultural runoff.
Majority of samples are above the permissible limits of BOD $(<2 \mathrm{mg} / \mathrm{L})$ and TC (100 MPN/100 mL) indicating unfit for domestic purpose (BIS 2012).

\section{Classification of surface water for designated use}

CPCB (2007) classified surface water in five quality class based on combine assessment of primary water parameters namely TC, DO, BOD, $\mathrm{pH}$ and $\mathrm{EC}$ for specific designated purpose (Table 8). It is important to note that evaluation of mutli-parameter provide concrete result rather than individual parameter. Surface water samples of the study area for both seasons are classified as per the guidelines of water quality criteria (CPCB 2007). Based on Table 8 , the number of samples fall in class $\mathrm{A}, \mathrm{B}, \mathrm{C}, \mathrm{D}$ and $\mathrm{E}$, respectively, are 1, 7, 8, 11, 18 for pre monsoon indicates that maximum number of samples are suitable for namely, propagation of wildlife and fisher and irrigation, industrial cooling and controlled disposal. Whereas during post monsoon 4, 10, 14, 16, 18 samples belong to class A, B, C, $\mathrm{D}$ and $\mathrm{E}$, respectively, indicating majority of samples are best suitable for more purposes, i.e., Outing bathing, drinking water source with conventional treatment, propagation of wildlife and fisher and irrigation, industrial cooling and controlled disposal. It is evident that significant temporal variation of surface water quality representing post monsoon season has better water quality as per the guidelines of water quality criteria (CPCB 2007). Such variation may be attributed to the increased volume of water and dilution from precipitation and self purification capacity of lotic system.

\section{Hydrochemical facies}

Hydrochemical facies reveals the analogies, dissimilarities and different types of water in the particular area 
Table 6 Suitability of water based on conductivity for irrigation (Source: CGWB and CPCB 1999)

\begin{tabular}{|c|c|c|c|c|c|c|}
\hline \multirow[t]{2}{*}{ Class } & \multirow{2}{*}{$\begin{array}{l}\text { Conductivity }(\mu \mathrm{mhos} / \\
\mathrm{cm})\end{array}$} & \multirow[t]{2}{*}{ Suitability or otherwise for irrigation } & \multicolumn{4}{|c|}{ Number of samples } \\
\hline & & & $\begin{array}{l}\text { Pre } \\
\text { monsoon }\end{array}$ & Percentage & $\begin{array}{l}\text { Post } \\
\text { monsoon }\end{array}$ & Percentage \\
\hline 1. & Below 250 & Entirely safe & NIL & NIL & NIL & NIL \\
\hline 2. & $\begin{array}{l}\text { 250-750 (moderately } \\
\text { Saline) }\end{array}$ & Safe practically under all conditions & 7 & 38.89 & 10 & 55.56 \\
\hline 3. & $\begin{array}{l}750-2250 \text { (medium to } \\
\text { high saline) }\end{array}$ & Safe with permeable soils and moderate leaching & 11 & 61.11 & 8 & 44.44 \\
\hline 4. & $\begin{array}{l}2250-4000 \text { (high } \\
\text { salinity) }\end{array}$ & $\begin{array}{l}\text { Used on soils with good permeability and with special leaching } \\
\text { for salt tolerant crops }\end{array}$ & NIL & NIL & NIL & NIL \\
\hline 5. & $\begin{array}{l}4000-6000 \text { (very high } \\
\text { salinity) }\end{array}$ & $\begin{array}{l}\text { Used only on highly permeable soils with frequent leaching with } \\
\text { plants of high salt tolerance }\end{array}$ & NIL & NIL & NIL & NIL \\
\hline 6. & $\begin{array}{l}\text { Above } 6000 \text { (excessive } \\
\text { Salinity) }\end{array}$ & This class represents water that is unfit for irrigation & NIL & NIL & NIL & NIL \\
\hline
\end{tabular}

Table 7 Different degree of hardness in water (Source: Durfor and Becker 1964)

\begin{tabular}{lllllll}
\hline S. no. & Hardness $(\mathrm{mg} / \mathrm{L})$ & Characteristics & \multicolumn{2}{l}{ Number of samples } & & \\
\cline { 5 - 7 } & & & Pre monsoon & Percentage & Post monsoon & Percentage \\
\hline 1. & $0-60$ & Very soft & NIL & NIL & NIL & NIL \\
2. & $61-120$ & Moderately soft & NIL & NIL & NIL & NIL \\
3. & $121-180$ & Hard & 6 & 33.33 & 2 & 11.11 \\
4. & $>180$ & Very hard & 12 & 66.67 & 16 & 88.89 \\
\hline
\end{tabular}

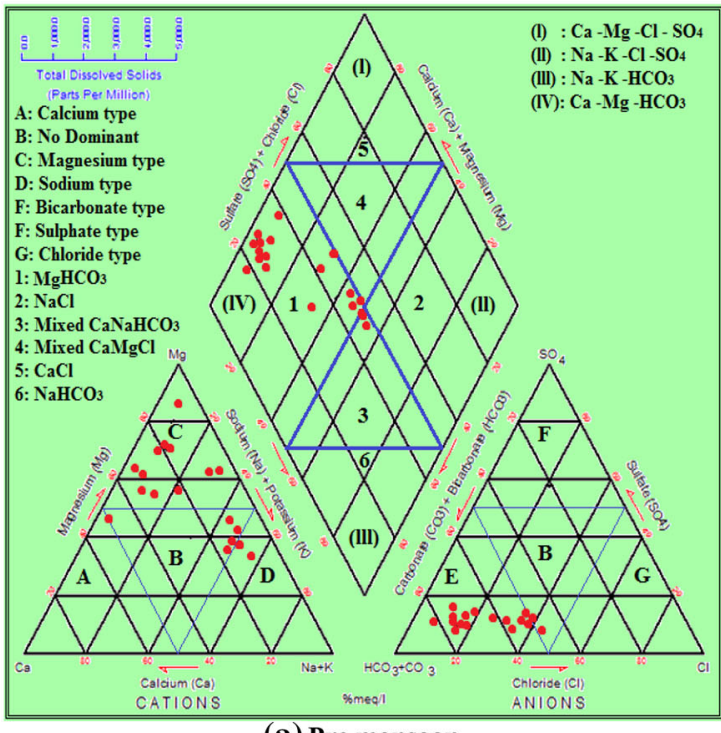

(a) Pre monsoon

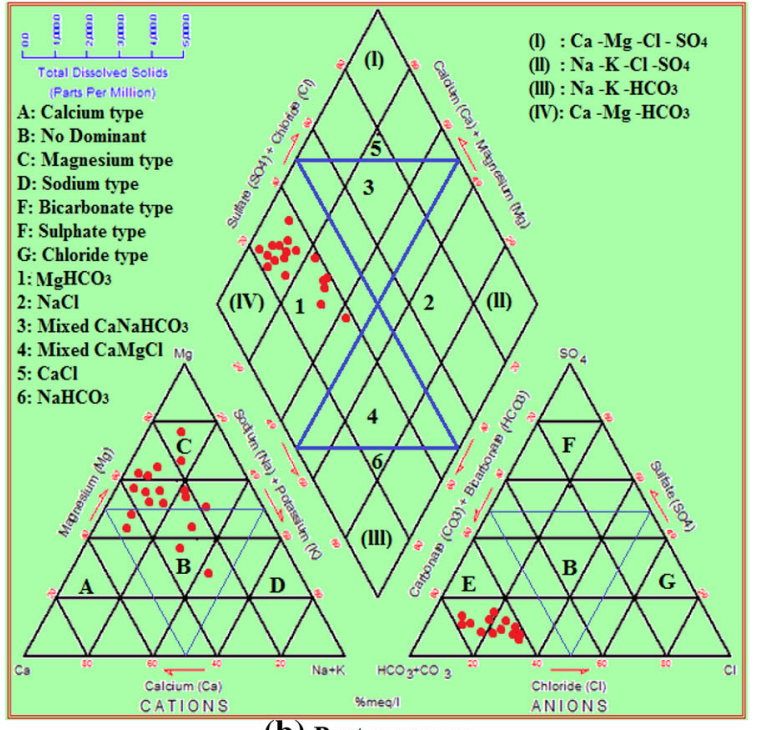

(b) Post monsoon

Fig. 4 Piper classification diagram illustrating the chemical composition of surface water

representing different characteristics belonging to any genetically related system. The graphical representations of facies are useful in identifying chemical processes and detecting the effects of mixing water within different lithological framework (Todd 1980). Various workers namely Collins (1923), Piper (1944, 1953), Black (1960), 
Table 8 Designated best use classification of surface water Source: Guidelines for water quality monitoring, MINARS/2007-08 (CPCB 2007)

\begin{tabular}{|c|c|c|c|c|}
\hline \multirow[t]{2}{*}{ Designates best use } & \multirow{2}{*}{$\begin{array}{l}\text { Quality } \\
\text { class }\end{array}$} & \multirow[t]{2}{*}{ Primary water quality criteria } & \multicolumn{2}{|c|}{ No of sample } \\
\hline & & & $\begin{array}{l}\text { Pre } \\
\text { monsoon }\end{array}$ & $\begin{array}{l}\text { Post } \\
\text { monsoon }\end{array}$ \\
\hline $\begin{array}{l}\text { Drinking water source without conventional treatment but with } \\
\text { chlorination }\end{array}$ & A & $\begin{array}{l}\text { TC }\left(\mathrm{MPN}^{\mathrm{a}} / 100 \mathrm{~mL}\right) \text { shall be } 50 \text { or } \\
\text { less } \\
\text { DO } 6 \mathrm{mg} / \mathrm{L} \text { or more } \\
\text { BOD } 2 \mathrm{mg} / \mathrm{L} \text { or less }\end{array}$ & 1 & 4 \\
\hline Outing bathing (organized) & $\mathrm{B}$ & $\begin{array}{l}\text { TC }\left(\mathrm{MPN}^{\mathrm{a}} / 100 \mathrm{~mL}\right) \text { shall be } 500 \text { or } \\
\text { less } \\
\text { DO } 5 \mathrm{mg} / \mathrm{L} \text { or more } \\
\text { BOD } 3 \mathrm{mg} / \mathrm{L} \text { or less }\end{array}$ & 7 & 10 \\
\hline Drinking water source with conventional treatment & $\mathrm{C}$ & $\begin{array}{l}\text { TC }\left(\mathrm{MPN}^{\mathrm{a}} / 100 \mathrm{~mL}\right) \text { shall be } 5000 \text { or } \\
\text { less } \\
\text { DO } 4 \mathrm{mg} / \mathrm{L} \text { or more } \\
\text { BOD } 3 \mathrm{mg} / \mathrm{L} \text { or less }\end{array}$ & 8 & 14 \\
\hline Propagation of wildlife and fisheries & $\mathrm{D}$ & DO $4 \mathrm{mg} / \mathrm{L}$ or more & 11 & 16 \\
\hline Irrigation, industrial cooling and controlled disposal & $\mathrm{E}$ & $\begin{array}{l}\mathrm{pH} \text { between } 6.5 \text { and } 8.5 \\
\text { Electrical conductivity less than } \\
2250 \mu \mathrm{S} / \mathrm{cm}\end{array}$ & 18 & 18 \\
\hline
\end{tabular}

${ }^{a} M P N$ most probable number

Walton (1970) and Chadha (1999) proposed the concept of graphical methods of representation of chemical analysis of water. In present study, Piper (1944) and Chadha (1999) diagrams were employed by plotting the concentration of major cations and anions for hydrochemical characterization of surface water. Rockworks 16 and Microsoft Excel 2007 software were used to construct Piper and Chadha diagram, respectively.

\section{Piper trilinear diagram}

The ionic concentrations were plotted in Piper diagram (Piper 1944) to characterize the hydrochemistry of the surface water in the study area (Fig. 4a, b; Table 9). Piper diagram shows that $83.33 \%$ of samples in $\mathrm{Ca}^{2+}-\mathrm{Mg}^{2+}$ $\mathrm{HCO}_{3}{ }^{-}$facies belong to temporary hardness while the remaining samples $(16.67 \%)$ fall under $\mathrm{Na}^{+}-\mathrm{K}^{+}-\mathrm{HCO}_{3}{ }^{-}$ facies due to base ion exchange processes exhibit sodium bicarbonate type wherein carbonate primary salinity during pre monsoon. All the surface water samples fall in $\mathrm{Ca}^{2+}-$ $\mathrm{Mg}^{2+}-\mathrm{HCO}_{3}{ }^{-}$, resulting $\mathrm{MgHCO}_{3}{ }^{-}$is the dominant facies in post monsoon. The graph also indicates that alkaline earth elements $\left(\mathrm{Ca}^{2+}+\mathrm{Mg}^{2+}\right)$ and weak acids $\left(\mathrm{CO}_{3}{ }^{2-}+\mathrm{HCO}_{3}{ }^{-}\right)$exceeded over the alkaline elements $\left(\mathrm{Na}^{+}+\mathrm{K}^{+}\right)$and strong acids $\left(\mathrm{SO}_{4}{ }^{2-}\right.$ and $\left.\mathrm{Cl}^{-}\right)$resulting $\mathrm{Mg}^{2+}$ and $\mathrm{HCO}_{3}{ }^{-}$are the principal cation and anion in surface water. Majority of surface water samples (83.33 and $100.00 \%$ ) for both seasons fall in the field of $\mathrm{Mg}^{2+}$ $\mathrm{HCO}_{3}{ }^{-}$water types having secondary salinity exceeding $50 \%$ which indicates inverse or reverse ion exchange
(Davis and Dewiest 1966; Tay 2012). Remaining 16.67\% sample for pre monsoon is $\mathrm{Ca}^{2+}-\mathrm{Na}^{+}-\mathrm{HCO}_{3}{ }^{-}$where types of water samples cannot be classified as neither cation- nor anion-dominant hydrochemical facies (Todd and Mays 2005; Herojeet et al. 2016).

\section{Chadha's plot}

Chadha's diagram is modified as well as improved version of Piper trilinear diagram (1944) and the expanded Durov diagram (1948). Chadha's diagram (1999) is used to identify the evolution of hydrochemical processes of surface water. In Chadha's diagram, the difference in milliequivalent percentage (percentage reacting values) between alkaline earths (calcium plus magnesium) and alkali metals (sodium plus potassium) is plotted on the $X$ axis and the difference between weak acidic anions (carbonate plus bicarbonate) and strong acidic anions (chloride plus sulfate) is plotted on the $Y$-axis. The four quadrant suggested by Chadha's graph explained mixing of natural water or recharging water, reverse ion exchange water, end seawater (saline water) and base ion exchange water. The upper right quadrant formed recharging water $\left(\mathrm{Ca}^{2+}-\mathrm{Mg}^{2+}-\mathrm{HCO}_{3}^{-}\right)$where surface runoff or standing water percolates to subsurface aquifers carrying dissolved $\mathrm{CO}_{3}{ }^{2-}$ or $\mathrm{HCO}_{3}{ }^{-}$and geochemically mobile $\mathrm{Mg}^{2+}$ or $\mathrm{Ca}^{2+}$ ions. Reverse ion exchange waters are less easily defined and less common, but represent groundwater where $\mathrm{Ca}^{2+}$ $\mathrm{Mg}^{2+}$ is in excess to $\mathrm{Na}^{+}-\mathrm{K}^{+}$either due to the preferential release of $\mathrm{Ca}^{2+}$ and $\mathrm{Mg}^{2+}$ from mineral weathering of 
Table 9 Surface water samples characterization based on Piper diagram

\begin{tabular}{|c|c|c|c|c|c|}
\hline \multirow[t]{3}{*}{ Class } & \multirow[t]{3}{*}{ Groundwater types corresponding subdivisions of facies } & \multicolumn{4}{|c|}{ Samples in the different category } \\
\hline & & \multicolumn{2}{|c|}{ Pre monsoon } & \multicolumn{2}{|c|}{ Post monsoon } \\
\hline & & $\begin{array}{l}\text { No. of } \\
\text { samples }\end{array}$ & Percentage & $\begin{array}{l}\text { No. of } \\
\text { samples }\end{array}$ & Percentage \\
\hline I & $\mathrm{Ca}^{2+}-\mathrm{Mg}^{2+}-\mathrm{Cl}^{-}-\mathrm{SO}_{4}{ }^{2-}$ & NIL & NIL & NIL & NIL \\
\hline II & $\mathrm{Na}^{+}-\mathrm{K}^{+}-\mathrm{Cl}^{-}-\mathrm{SO}_{4}{ }^{2-}$ & NIL & NIL & NIL & NIL \\
\hline III & $\mathrm{Na}^{+}-\mathrm{K}^{+}-\mathrm{HCO}_{3}^{-}$ & 3 & 16.67 & NIL & NIL \\
\hline IV & $\mathrm{Ca}^{2+}-\mathrm{Mg}^{2+}-\mathrm{HCO}_{3}^{-}$ & 15 & 83.33 & 18 & 100 \\
\hline A & Calcium type & NIL & NIL & NIL & NIL \\
\hline B & No dominant (cations) & 5 & 27.78 & 5 & 27.78 \\
\hline $\mathrm{C}$ & Magnesium type & 11 & 61.11 & 13 & 72.22 \\
\hline $\mathrm{D}$ & Sodium type & 2 & 11.11 & NIL & NIL \\
\hline $\mathrm{E}$ & Bicarbonate type & 15 & 83.33 & 18 & 100 \\
\hline B & No dominant (anions) & 3 & 16.67 & NIL & NIL \\
\hline $\mathrm{F}$ & Sulfate type & NIL & NIL & NIL & NIL \\
\hline G & Chloride type & NIL & NIL & NIL & NIL \\
\hline 1 & $\begin{array}{l}\mathrm{HCO}_{3}{ }^{-}-\mathrm{CO}_{3}^{2-} \text { and } \mathrm{Ca}^{2+}-\mathrm{Mg}^{2+} \text { (temporary hardness); magnesium bicarbonate type } \\
\quad \text { (carbonate hardness exceeds } 50 \% \text { ) }\end{array}$ & 15 & 83.33 & 18 & 100 \\
\hline 2 & $\begin{array}{l}\mathrm{Cl}^{-}-\mathrm{SO}_{4}{ }^{2-} \text { and } \mathrm{Na}^{+}-\mathrm{K}^{+} \text {(saline); sodium chloride type (non-carbonate alkali exceeds } \\
50 \% \text { ) }\end{array}$ & NIL & NIL & NIL & NIL \\
\hline 3 & Mixing Zone $\left(\mathrm{Ca}^{2+}-\mathrm{Na}^{+}-\mathrm{HCO}_{3}{ }^{-}\right)$; Base ion exchange processes & 3 & 16.67 & NIL & NIL \\
\hline 4 & Mixing Zone $\left(\mathrm{Ca}^{2+}-\mathrm{Mg}^{2+}-\mathrm{Cl}^{-}\right)$; reverse ion exchange processes & NIL & NIL & NIL & NIL \\
\hline 5 & $\begin{array}{l}\mathrm{Cl}^{-}-\mathrm{SO}_{4}{ }^{2-} \text { and } \mathrm{Ca}^{2+}-\mathrm{Mg}^{2+} \text { (permanent hardness); calcium chloride type (non- } \\
\text { carbonate hardness exceeds } 50 \% \text { ) }\end{array}$ & NIL & NIL & NIL & NIL \\
\hline 6 & $\begin{array}{l}\mathrm{HCO}_{3}{ }^{-}-\mathrm{CO}_{3}{ }^{2-} \text { and } \mathrm{Na}^{+}-\mathrm{K}^{+} \text {(alkali carbonate); sodium bicarbonate type (carbonate } \\
\quad \text { alkali exceeds } 50 \% \text { ) }\end{array}$ & NIL & NIL & NIL & NIL \\
\hline
\end{tabular}

exposed bedrock or possibly reverse base cation exchange reactions of $\mathrm{Ca}^{2+}-\mathrm{Mg}^{2+}$ into solution and subsequent adsorption of $\mathrm{Na}^{+}$onto mineral surfaces. The upper left quadrant represents base ion exchange of water from $\mathrm{Ca}^{2+}-\mathrm{HCO}_{3}{ }^{-}$fresh water type mixed with $\mathrm{Na}^{+}-\mathrm{Cl}^{-}$ salinity water type to produce $\mathrm{Na}^{+}-\mathrm{HCO}_{3}{ }^{-}$(carbonate primary salinity) through ion exchange processes. Finally, the lower left quadrant indicate seawater types are commonly occurred to the coastal or bay or estuaries region with $\mathrm{Na}^{+}-\mathrm{Cl}^{-}$(non carbonate primary salinity) dominant ions resulting seawater mixing. To define the primary character of water, the rectangular field is divided into eight sub-fields, each of which represents a water type (Table 10).

The results of Chadha's classification for surface water observed that during pre monsoon season 12 samples $(66.67 \%)$ fall in recharge water Group $5\left(\mathrm{Ca}^{2+}-\mathrm{Mg}^{2+}\right.$ $\mathrm{HCO}_{3}{ }^{-}$type or $\mathrm{Ca}^{2+}-\mathrm{Mg}^{2+}$ dominant $\mathrm{HCO}_{3}{ }^{-}$type or $\mathrm{HCO}_{3}{ }^{-}$dominant $\mathrm{Ca}^{2+}-\mathrm{Mg}^{2+}$ type) indicates temporary hardness and six samples $(33.33 \%)$ in base ion exchange Group $8\left(\mathrm{Na}^{+}-\mathrm{K}^{+}-\mathrm{HCO}_{3}{ }^{-}\right.$type or $\mathrm{Na}^{+}-\mathrm{K}^{+}$dominant $\mathrm{HCO}_{3}{ }^{-}$type or $\mathrm{HCO}_{3}{ }^{-}$dominant $\mathrm{Na}^{+}-\mathrm{K}^{+}$type) depicts alkali carbonate enrichment water type by dissolution or
Table 10 Summarized results of Chadha's classification

\begin{tabular}{lll}
\hline Classification/type & \multicolumn{2}{l}{ Surface water } \\
\cline { 2 - 3 } & \multicolumn{2}{l}{ No. of samples } \\
\cline { 2 - 3 } & Pre monsoon & Post monsoon \\
\hline Group 1 $\left(\mathrm{Ca}^{2+}-\mathrm{Mg}^{2+}-\mathrm{Na}^{+}-\mathrm{K}^{+}\right)$ & $12(66.67 \%)$ & $16(88.89 \%)$ \\
Group 2 $\left(\mathrm{Na}^{+}-\mathrm{K}^{+}-\mathrm{Ca}^{2+}-\mathrm{Mg}^{2+}\right)$ & $6(33.33 \%)$ & $2(11.11 \%)$ \\
Group 3 $\left(\mathrm{HCO}_{3}{ }^{-}-\mathrm{Cl}^{-}-\mathrm{SO}_{4}{ }^{2-}\right)$ & $18(100 \%)$ & $18(100 \%)$ \\
Group $4\left(\mathrm{SO}_{4}{ }^{2-}-\mathrm{HCO}_{3}{ }^{-}-\mathrm{Cl}^{-}\right)$ & $\mathrm{NIL}$ & NIL \\
Group 5 $\left(\mathrm{Ca}^{2+}-\mathrm{Mg}^{2+}-\mathrm{HCO}_{3}{ }^{-}\right)$ & $12(66.67 \%)$ & $16(88.89 \%)$ \\
Group 6 $\left(\mathrm{Ca}^{2+}-\mathrm{Mg}^{2+}-\mathrm{Cl}^{-}-\mathrm{SO}_{4}{ }^{2-}\right)$ & NIL & NIL \\
Group 7 $\left(\mathrm{Na}^{+}-\mathrm{K}^{+}-\mathrm{Cl}^{-}-\mathrm{SO}_{4}{ }^{2-}\right)$ & NIL & NIL \\
Group $8\left(\mathrm{Na}^{+}-\mathrm{K}^{+}-\mathrm{HCO}_{3}{ }^{-}\right)$ & $6(33.33 \%)$ & $2(11.11 \%)$ \\
\hline
\end{tabular}

weathering of halite mineral characterize primary salinity (Ravikumar and Somashekar 2015) (Fig. 5a). However, 16 samples $(88.89 \%)$ fall in recharge water Group $5\left(\mathrm{Ca}^{2+}\right.$ $\mathrm{Mg}^{2+}-\mathrm{HCO}_{3}{ }^{-}$) except for 2 samples (11.11\%) which belong to base ion exchange Group $8\left(\mathrm{Na}^{+}-\mathrm{K}^{+}-\mathrm{HCO}_{3}{ }^{-}\right.$ type) during post monsoon (Fig. 5b). It is evident from Chadha's diagram that there is temporal variation in 


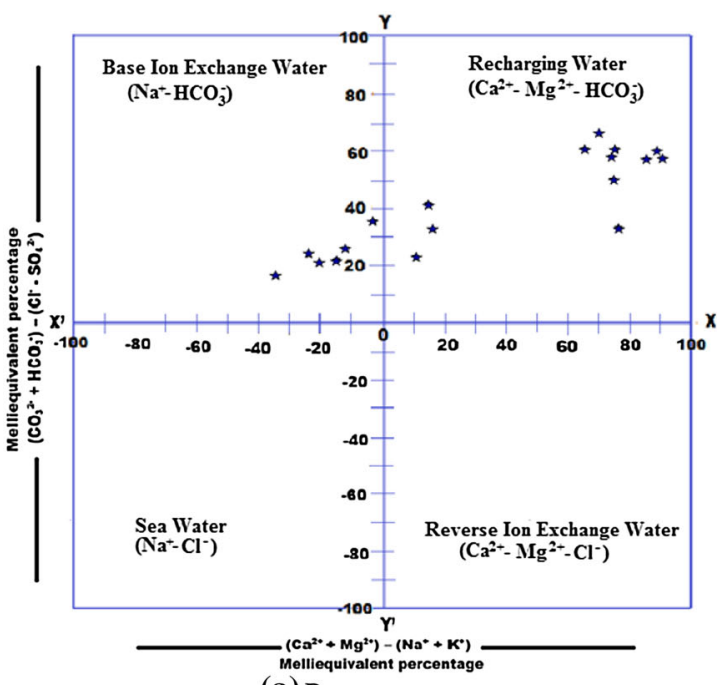

(a) Pre monsoon

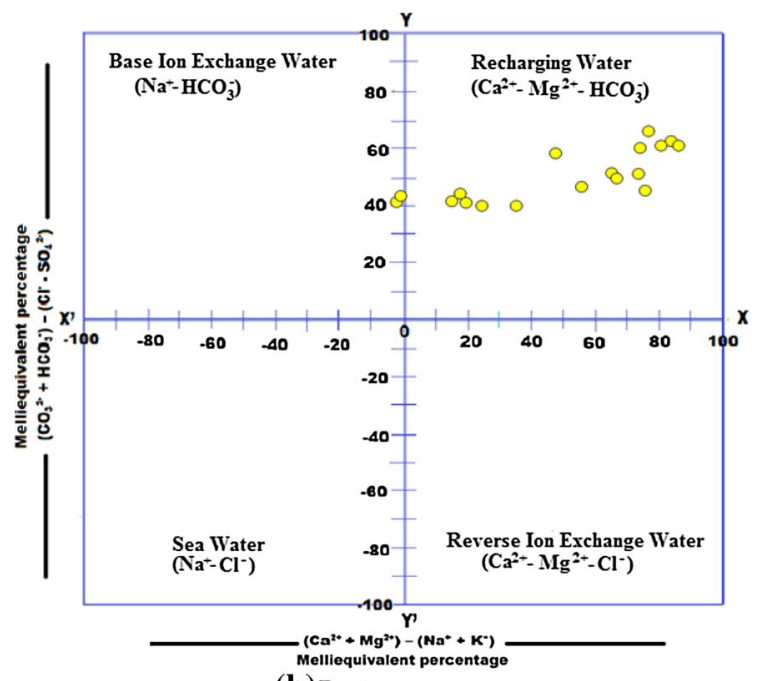

(b) Post monsoon

Fig. 5 Diagram showing Chadha's classification of surface water

surface water chemistry as certain samples contain a high concentration of bicarbonate ions to precipitate $\mathrm{Ca}^{2+}$ and $\mathrm{Mg}^{2+}$ ions which may deposit residual sodium carbonate in irrigation use and cause foaming problems during pre monsoon and post monsoon.

The output of Piper trilinear diagram is confirmed with the Chadha's plot that maximum samples for surface water belong to alkaline earths and weak acidic anions exceed alkali metals and strong acidic anions, as $\mathrm{Ca}^{2+}-\mathrm{Mg}^{2+}$ $\mathrm{HCO}_{3}{ }^{-}$water type for both seasons, respectively. Only few samples of surface water fall in alkali metals exceed alkaline earths and weak acidic anions exceed strong acidic anions as indicated by $\mathrm{Na}^{+}-\mathrm{HCO}_{3}{ }^{-}$type of water.

\section{Pollution source identification of surface water}

Multivariate statistical techniques such as PCA and CA have been applied on the analyzed parameters of surface water to distinguish the pollution sources during pre and post monsoon seasons, respectively.

Principal components (PCs) are extracted by the scree plot method considering the eigenvalues more than 1 (Shrestha and Kazama 2007). The calculated component loadings, cumulative percentage and percentages of variance explained by each factor are listed in Table 11. Principal components (PC's) corresponding to absolute loading values of $>0.75$ (marked bold in the table) and additionally second level of interpretation (bold plus italics) are taken into consideration as statistically significant in the interpretation by PCA. Four PCs were extracted by varimax rotation methods (Singh et al. 2004, 2005; Herojeet et al. 2016) which explains about 81.2 and $83.6 \%$ of the total variance, respectively, for pre and post monsoon seasons.
During pre monsoon, PC1 explains $42.2 \%$ of total variance that has strong positive loadings on $\mathrm{Na}^{+}, \mathrm{K}^{+}$, $\mathrm{HCO}_{3}{ }^{-}, \mathrm{Cl}^{-}$and $\mathrm{SO}_{4}{ }^{2-}$ and moderately with BOD which are controlled by lithogenic factors and various hydrogeochemical processes resulting in high EC and TDS scores (mineralized water). This condition can be associated with weathering of silicate, limestone, halite and pyrite dissolution (Okiongbo and Douglas 2015; Ravikumar and Somashekar 2015). The strong loading of $\mathrm{Na}^{+}$and $\mathrm{K}^{+}$with $\mathrm{HCO}_{3}{ }^{-}, \mathrm{Cl}^{-}$and $\mathrm{SO}_{4}{ }^{2-}$ ions indicates natural weathering of rock minerals and various ion exchange processes in the water system (Srivastava and Ramanathan 2008). The high positive loading of $\mathrm{HCO}_{3}{ }^{-}$and $\mathrm{SO}_{4}{ }^{2-}$ is attributed to the reaction of feldspar, pyroxene, amphiboles and biolite minerals with carbonic acid in the presence of water (Amadi et al. 1987; Elango et al. 2003). $\mathrm{SO}_{4}{ }^{2-}$ ions associated with higher concentration of $\mathrm{Na}^{+}$may cause laxative and gastric disorder (Herojeet et al. 2015a, 2016). Moreover, moderate BOD score indicates natural water quality and least intervention from human activities.

PC2 accounts for $18.0 \%$ of the total variance with strong negative weight on BOD and TC and moderate negative score with $\mathrm{Ca}^{2+}$ and $\mathrm{NO}_{3}{ }^{-}$. This may be attributed to anthropogenic factor linked to domestic wastewater discharge and surface runoff from river catchment containing soil minerals and nitrogen species which increased the biological activity. Esakkimuthu et al. (2015) have reported that strong absolute loadings on BOD and TC indicate organic pollution from human activities. Surface water contaminated with TC causes cholera, diarrhea, dysentery and skin, eye, and throat infections (Hammer 1986; WHO 1993). PC 3 is responsible for $12.2 \%$ of the total variance, strong positive score on $\mathrm{TH}$ and $\mathrm{Mg}^{2+}$ and may be attributed to natural factor from the dissolution of silicate and 
Table 11 Varimax rotated component matrix of analyzed water samples

\begin{tabular}{|c|c|c|c|c|c|c|c|c|}
\hline \multirow[t]{2}{*}{ Variables } & \multicolumn{4}{|c|}{ Component (pre monsoon) } & \multicolumn{4}{|c|}{ Component (post monsoon) } \\
\hline & $\mathrm{PC} 1$ & PC2 & PC3 & PC4 & $\mathrm{PC} 1$ & $\mathrm{PC} 2$ & PC3 & PC4 \\
\hline $\mathrm{pH}$ & 0.274 & 0.439 & 0.092 & -0.612 & -0.312 & -0.332 & -0.547 & 0.607 \\
\hline $\mathrm{EC}$ & 0.970 & 0.141 & -0.143 & 0.085 & 0.977 & 0.026 & -0.112 & 0.075 \\
\hline TDS & 0.968 & 0.148 & -0.146 & 0.074 & 0.976 & -0.004 & -0.124 & 0.080 \\
\hline $\mathrm{TH}$ & 0.419 & 0.280 & 0.801 & 0.098 & 0.082 & -0.482 & 0.829 & 0.095 \\
\hline $\mathrm{Ca}^{2+}$ & 0.223 & -0.516 & 0.309 & 0.316 & 0.218 & -0.324 & 0.075 & -0.836 \\
\hline $\mathrm{Mg}^{2+}$ & 0.362 & 0.452 & 0.729 & 0.002 & -0.019 & -0.332 & 0.795 & 0.485 \\
\hline $\mathrm{Na}^{+}$ & 0.829 & 0.327 & -0.257 & -0.057 & 0.878 & 0.369 & -0.070 & 0.064 \\
\hline $\mathrm{K}^{+}$ & 0.889 & 0.020 & -0.161 & -0.023 & 0.927 & 0.260 & 0.097 & 0.100 \\
\hline $\mathrm{HCO}_{3}{ }^{-}$ & 0.795 & -0.063 & -0.185 & 0.291 & 0.758 & 0.366 & 0.013 & -0.109 \\
\hline $\mathrm{Cl}^{-}$ & 0.842 & 0.433 & -0.289 & 0.083 & 0.745 & 0.605 & 0.109 & 0.064 \\
\hline $\mathrm{SO}_{4}^{2-}$ & 0.859 & -0.014 & 0.095 & 0.225 & 0.868 & -0.336 & -0.222 & 0.198 \\
\hline $\mathrm{NO}_{3}{ }^{-}$ & 0.505 & -0.545 & 0.479 & 0.121 & 0.607 & -0.501 & -0.412 & -0.012 \\
\hline $\mathrm{PO}_{4}{ }^{3-}$ & -0.054 & 0.479 & 0.370 & -0.436 & 0.541 & 0.684 & 0.305 & 0.157 \\
\hline DO & -0.446 & 0.248 & 0.146 & 0.691 & -0.798 & 0.304 & -0.197 & 0.205 \\
\hline BOD & 0.514 & -0.744 & 0.169 & -0.303 & 0.689 & -0.650 & -0.210 & 0.089 \\
\hline TC & 0.451 & -0.807 & 0.021 & -0.326 & 0.653 & -0.609 & 0.209 & -0.060 \\
\hline Eigen value & 6.7898 & 2.8765 & 1.9543 & 1.5246 & 7.7694 & 2.9799 & 2.1166 & 1.47 .5 \\
\hline Cumulative $\%$ of variance & 42.4 & 60.4 & 72.6 & 82.1 & 48.6 & 61.2 & 74.4 & 83.6 \\
\hline$\%$ of variance & 42.4 & 18.0 & 12.2 & 9.5 & 48.6 & 18.6 & 13.2 & 9.2 \\
\hline
\end{tabular}

$P C$ principal component

magnesium bearing minerals. Among the cations, $\mathrm{Mg}^{2+}$ is the dominant ions contributing hardness in water. Additionally, $9.5 \%$ of the total variance is explained by PC4 that indicates positive score with DO (moderate) and negatively correlated with $\mathrm{pH}$ (moderate), reflects natural water system to support aquatic life. It may be noted that increased pH (slightly alkaline conditions) and high DO are the favorable environment to sustain aquatic animals.

For post monsoon, $\mathrm{PC} 1$ explains that $48.6 \%$ of the total variance has strong positive correlation on EC, TDS, $\mathrm{Na}^{+}$, $\mathrm{K}^{+}, \mathrm{HCO}_{3}{ }^{-}$and $\mathrm{SO}_{4}{ }^{2-}$, moderate positive score on $\mathrm{Cl}^{-}$, $\mathrm{NO}_{3}{ }^{-}, \mathrm{PO}_{4}{ }^{2-}, \mathrm{BOD}$ and $\mathrm{TC}$, and negative loading on $\mathrm{pH}$ (weak) and DO (moderate). The combination of EC, TDS, $\mathrm{Na}^{+}, \mathrm{K}^{+}, \mathrm{HCO}_{3}{ }^{-}, \mathrm{Cl}^{-}$and $\mathrm{SO}_{4}{ }^{2-}$ ions, indicates weathering of minerals (lithogenic factor) associated with hydrochemistry (Okiongbo and Douglas 2015). The chemical species $\mathrm{NO}_{3}{ }^{-}$and $\mathrm{PO}_{4}{ }^{2-}$ stimulates increased BOD and TC level, which may be due to industrial and domestic effluent and agricultural runoff (Iscen et al. 2008; Dinkaa et al. 2015). The negative loading of $\mathrm{pH}$ and DO represents the organic contamination from human activities (Muangthong and Shrestha 2015; Hamid et al. 2016). Kim et al. $(2003,2005)$ suggested that negative loading of $\mathrm{pH}$ and DO is due to organic contamination, resulting in the formation of ammonia and organic acids thereby decreasing $\mathrm{pH}$ and affecting aquatic life. Hence, it can be inferred that PC1 is controlled by mixed factor (lithogenic and anthropogenic). PC2 accounts for $18.6 \%$ of the total variance and moderate positive loading on $\mathrm{Cl}^{-}$and $\mathrm{PO}_{4}{ }^{2-}$ and negative score (moderate) with $\mathrm{NO}_{3}{ }^{-}$, BOD and TC. The significant inverse relationship between $\mathrm{Cl}^{-}$and $\mathrm{PO}_{4}{ }^{2-}$ and $\mathrm{NO}_{3}{ }^{-}$could be due to different source of chemical origin. Increase in nutrient concentration, primarily $\mathrm{PO}_{4}{ }^{2-}$ and $\mathrm{NO}_{3}{ }^{-}$, enhanced biological metabolism thereby decreasing dissolved oxygen (Hickman and Gray 2010; Nyamangara et al. 2013). It is noted that the study area lacks proper sewage drainage system and also encounters tremendous surface/urban runoff (effluent) during monsoon season. This component is attributed to anthropogenic factor (agricultural runoff and domestic sewage). PC3 is responsible for $13.2 \%$ of the total variance with strong positive loading on $\mathrm{TH}$ and $\mathrm{Mg}^{2+}$, which are controlled by lithogenic factor. Boyd and Tucker (1998) depict that the degree of water hardness increased with the elevated concentration of $\mathrm{Mg}^{2+}$ ions. Lastly, $9.2 \%$ of the total variance is explained by $\mathrm{PC} 4$ that indicates positive loading on $\mathrm{pH}$ (moderate) and negative weight with $\mathrm{Ca}^{2+}$ (strong), represent natural water quality formed due to rock water interaction. Alkaline $\mathrm{pH}$ enables $\mathrm{Ca}^{2+}$ to precipitate as calcium carbonate.

CA is employed to sort out the similarities and differences between the 18 sampling locations of surface water by dendrogram. The clustering pattern formed by each cluster cannot be explained by considering certain special 
Table 12 Average values of the water quality parameters for each cluster

\begin{tabular}{|c|c|c|c|c|c|c|}
\hline \multirow{2}{*}{$\begin{array}{l}\text { Cluster } \\
\text { parameter }\end{array}$} & \multicolumn{3}{|l|}{ Pre monsoon } & \multicolumn{3}{|l|}{ Post monsoon } \\
\hline & $\begin{array}{l}\text { Cluster } 1(1,2,3,6 \text {, } \\
16,4,5,12)\end{array}$ & $\begin{array}{l}\text { Cluster } \\
2(7)\end{array}$ & $\begin{array}{l}\text { Cluster } 3(8,9,10,13,14, \\
18,15,17,11)\end{array}$ & $\begin{array}{l}\text { Cluster } 1(1,2,4,6,3,5,10 \text {, } \\
12,16,17)\end{array}$ & $\begin{array}{l}\text { Cluster } \\
2(7)\end{array}$ & $\begin{array}{l}\text { Cluster } 3(8,9,13,15 \text {, } \\
11,14,18)\end{array}$ \\
\hline $\mathrm{pH}$ & 7.44 & 7.54 & 7.60 & 7.46 & 7.54 & 7.25 \\
\hline EC & 683.66 & 1490.00 & 1386.33 & 582.30 & 1512.00 & 931.57 \\
\hline TDS & 441.50 & 969.0 & 905.00 & 376.40 & 1014.00 & 602.14 \\
\hline TH & 199.25 & 261.0 & 245.22 & 245.20 & 261.00 & 243.43 \\
\hline $\mathrm{Ca}^{2+}$ & 35.11 & 79.0 & 37.47 & 61.41 & 79.00 & 67.65 \\
\hline $\mathrm{Mg}^{2+}$ & 40.05 & 44.41 & 52.89 & 44.85 & 44.41 & 42.89 \\
\hline $\mathrm{Na}^{+}$ & 12.16 & 130.00 & 146.69 & 24.49 & 130.00 & 95.61 \\
\hline $\mathrm{K}^{+}$ & 1.98 & 9.00 & 8.60 & 2.92 & 9.00 & 7.11 \\
\hline $\mathrm{HCO}_{3}{ }^{-}$ & 7.32 & 17.00 & 33.46 & 9.54 & 17.00 & 22.87 \\
\hline $\mathrm{Cl}^{-}$ & 112.00 & 145.00 & 138.89 & 116.80 & 145.00 & 143.43 \\
\hline $\mathrm{SO}_{4}^{2-}$ & 2.01 & 17.89 & 4.42 & 3.64 & 18.00 & 2.74 \\
\hline $\mathrm{NO}_{3}^{-}$ & 10.72 & 23.00 & 17.89 & 11.63 & 23.00 & 13.34 \\
\hline $\mathrm{PO}_{4}{ }^{3-}$ & 0.15 & 0.03 & 0.18 & 0.03 & 0.03 & 0.07 \\
\hline DO & 4.66 & 0.00 & 3.94 & 7.44 & 0.00 & 4.80 \\
\hline BOD & 2.46 & 280.00 & 13.00 & 1.03 & 170.00 & 7.36 \\
\hline $\mathrm{TC}$ & 131.76 & 1600.00 & 168.44 & 84.20 & 765.00 & 178.43 \\
\hline
\end{tabular}

Bold indicates the highest average value paramters among different clusters

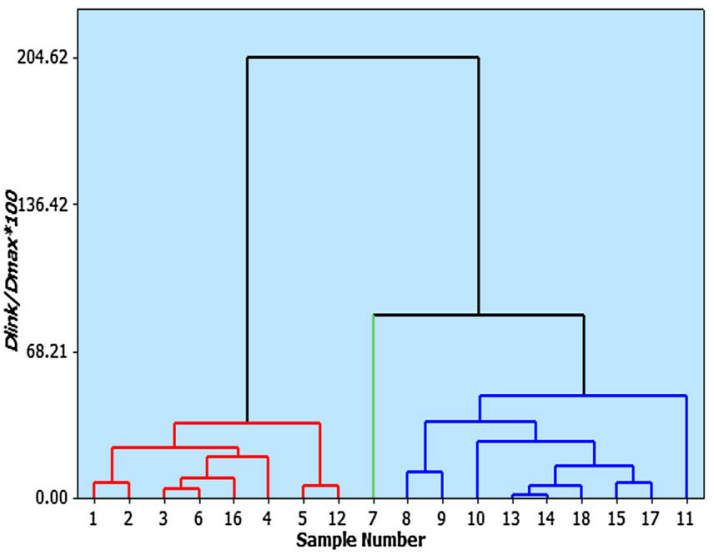

(a)Pre monsoon

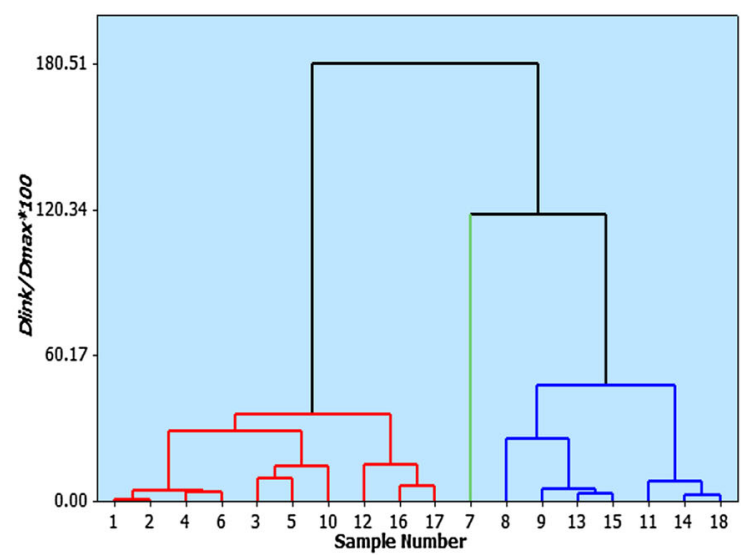

(b) Post monsoon

Fig. 6 Hierarchical dendogram of sampling locations in the study area

parameters only. Therefore, specific tracers for each pattern representing individual cluster need to be identified by calculating the average value of each parameter belonging to the individual clusters. Dendrogram reveals three statistically significant clusters $\left(D_{\text {link }} / D_{\text {max }}\right) \times 100<70$ (pre monsoon) and $\left(D_{\text {link }} / D_{\max }\right) \times 100<60$ (post monsoon) for water samples, respectively, and their average values are listed in Table 12 and Fig. 6a, b.

During pre monsoon, Cluster $1(\mathrm{C} 1)$ confirms a pattern with the highest level of DO and low tracer $\mathrm{pH}$, corresponds well with PC4. The sampling locations belonging to
$\mathrm{C} 1(1,2,3,6,16,4,5,12)$ indicate natural water quality. The smallest cluster 2 (C2) is represented by single sample (7) and the highest levels of EC, TDS, TH, $\mathrm{Ca}^{2+}, \mathrm{K}^{+}, \mathrm{Cl}^{-}$, $\mathrm{SO}_{4}{ }^{2-} \mathrm{NO}_{3}{ }^{-}$, BOD and $\mathrm{TC}$, which may be attributed to the mixed factor (anthropogenic and lithogenic). C2 correlates fairly well with PC1 and PC2. The largest group of sampling locations $(8,9,10,13,14,18,15,17,11)$ belonging to cluster $3(\mathrm{C} 3)$ confirms the highest level of $\mathrm{pH}, \mathrm{Mg}^{2+}$, $\mathrm{K}^{+}$and $\mathrm{HCO}_{3}{ }^{-}$and embodies lithogenic factor (weathering and leaching of minerals) controlling the hydrochemistry as in PC3. 
The dataset obtained in post monsoon also displayed 3 clusters. The first cluster $\mathrm{C} 1$ is the largest group of sampling locations $(1,2,4,6,3,5,10,12,16,17)$ forms a pattern of highest level of $\mathrm{Mg}^{2+}$ and DO indicate natural water attributed to dissolution of minreals and favourable for the existence of aquatic life. $\mathrm{C} 1$ fairly correlates with $\mathrm{PC} 3$. The intermediate cluster $\mathrm{C} 2$ (7) confirms the highest level of $\mathrm{pH}, \mathrm{EC}, \mathrm{TDS}, \mathrm{TH}, \mathrm{Ca}^{2+}, \mathrm{Na}^{+}, \mathrm{K}^{+}, \mathrm{Cl}^{-}, \mathrm{SO}_{4}{ }^{2-}$, $\mathrm{NO}_{3}{ }^{-}, \mathrm{BOD}$ and $\mathrm{TC}$, and corresponds well with $\mathrm{PC} 1$ and PC4. It signifies that the sampling location is polluted from lithogenic and anthropogenic factors. Lastly, Cluster 3 (C3) is distinguished by the highest level of $\mathrm{HCO}_{3}{ }^{-}$and $\mathrm{PO}_{4}{ }^{3-}$, which correlates well with $\mathrm{PC} 2$. The sampling locations group of C3 $(8,9,13,15,11,14,18)$ may be attributed to the anthropogenic factor (domestic sewage and agricultural runoff) (Nyamangara et al. 2013).

CA has been incorporated to assess the relationships and validate the sources identified by PCA.

The sampling locations group in $\mathrm{C} 1$ are influenced by lithogenic factor, whereas $\mathrm{C} 2$ by mixed factor, respectively, for both seasons. However, C3 sampling locations are controlled by lithogenic factor for pre monsoon, whereas during post monsoon by anthropogenic factor. Few sampling locations $(10,17)$ of $\mathrm{C} 3$ during pre monsoon are grouped under $\mathrm{C} 1$ of post monsoon. The remaining sampling locations grouped in $\mathrm{C} 3(8,9,13,15,11,14,18)$ for both seasons are influenced by different sources. It indicates that same sampling locations are influenced by temporal variation of pollution sources, changing human activities related to seasonality like agriculture and excessive surface runoff often loaded with industrial and domestic effluents during monsoon and post monsoon period. The area also lacks proper drainage system where effluents are directly discharged into local tributaries and enters Sirsa river. CA supported by PCA confirms that the surface water chemistry is strongly controlled by natural factors such as weathering of minerals, ion exchange processes and anthropogenic factors. Hence, a good relation between the two statistical techniques (PCA and CA) is elucidated from the analyzed datasets of water samples.

\section{Conclusion}

This paper highlights the application of multivariate statistical analysis and conventional graphical hydrochemical representation to assess the hidden factor controlling hydrochemistry and geochemical evolution processes of water system. The physicochemical parameters are within the permissible limits of BIS (2012) and WHO (2011), except for EC (both seasons), $\mathrm{Mg}^{2+}, \mathrm{Na}^{+}$and $\mathrm{K}^{+}$(pre monsoon), respectively. However, the biological indictors namely BOD and TC show majority of the samples are above the prescribed limits of BIS (2012) indicating organic pollution. The irrigation suitability for EC values falls moderately to high saline whereas TDS values belong to fresh water class. The result of Piper plot and Chadha's classification confirms that majority of samples for both seasons fall under $\mathrm{Ca}^{2+}-\mathrm{Mg}^{2+}-\mathrm{HCO}_{3}{ }^{-}$water types indicating temporary hardness and remaining few samples belong to $\mathrm{Ca}^{2+}-\mathrm{Na}^{+}-\mathrm{HCO}_{3}{ }^{-}$or $\mathrm{Na}^{+}-\mathrm{HCO}_{3}{ }^{-}$forms by base ion exchange processes. Based on the conventional hydrochemical study, the influence of ion exchange processes attributes the dominance of alkaline earth metals over the alkali metals and weak acidic anions over strong acidic anions in the study area. PCA and CA identify the surface water chemistry is strongly controlled by natural factors such as weathering of minerals, ion exchange processes and anthropogenic factors like agricultural runoff and discharge of industrial and domestic effluent. Thus, the holistic approach of PCA and CA modeling will help to plan the future design through optimal sampling locations based on seasons without losing any outcome significance and develop remedial measures for the restoration of water resources.

Acknowledgements The authors are thankful to the Chairperson, Department of Environment Studies and Department of Geology (CAS), Panjab University, Chandigarh, for providing necessary research facilities. I would also like to express my sincere gratitude to Professor Veena Dadwal, incharge of Physico-Chemical Laboratory and Mr. Kuldeep, Lab. technician, Department of Geology (CAS), for their help and co-operation during analysis.

Open Access This article is distributed under the terms of the Creative Commons Attribution 4.0 International License (http:// creativecommons.org/licenses/by/4.0/), which permits unrestricted use, distribution, and reproduction in any medium, provided you give appropriate credit to the original author(s) and the source, provide a link to the Creative Commons license, and indicate if changes were made.

\section{References}

Adams S, Titus R, Pietesen K, Tredoux G, Harris C (2001) Hydrochemical characteristic of aquifers near Sutherland in the Western Karoo, South Africa. J Hydro 241:91-103

Amadi PA, Ofoegbu CO, Morrison T (1987) Hydrogeochemical assessment of groundwater quality in parts of the Niger Delta, Nigeria. Environ Geol Water Sci 14:195-202

Anonymous (2014) Report of people's public hearing on industrial pollution in Baddi Barotiwala Nalagarh industrial area. Him parivesh environment protection organisation and Himdhara environment research and action collective. pp 1-48. http:// www.himdhara.org/wpcontent/uploads/2014/06/BBN-PHReport-5th-June-2014.pdf

Anshu S, Kr Ravi, Vikas G, Gaurav A, Shakun S, Indu S (2011) Water quality assessment of Ramganga river at Moradabad by physico-chemical parameters analysis. VSRD-TNTJ 2(3):119-127 
APHA, AWWA, WEF (2005) Standard methods for the examination of water and waste water, 21st edn. American Public Health Association, American Water Works Association and Water Environment Federation, New York

Bhutiani R, Khanna DR, Kulkarni DB, Ruhela M (2016) Assessment of Ganga river ecosystem at Haridwar, Uttarakhand, India with reference to water quality indices. Appl Water Sci 6:107-113

Biglin A, Konanc MU (2016) Evaluation of surface water quality and heavy metal pollution of Coruh river basin (Turkey) by multivariate statistical methods. Environ Earth Sci 75:1029

BIS (2012) Indian standard drinking water specification IS:10500, 2nd edn. Indian Standard Institute, New Delhi, pp 1-18

Black W (1960) Hydrochemical facies and groundwater flow patterns in northern part of Atlantic coastal plain. US Geol Surv 498A:42

Boyacioglu H (2006) Surface water quality assessment using factor analysis. Water S A 32(3):389-393

Boyd CE, Tucker CS (1998) Pond aquaculture water quality management. Kluwer Academic, Norwell

Bricker OP, Jones BF (1995) Main factors affecting the composition of natural waters. In: Salbu B, Steinnes E (eds) Trace elements in natural waters. CRC, Boca Raton, pp 1-5

Central Groundwater Board and Central Pollution Control Board (1999) Status of groundwater quality and pollution aspect in NCT-Delhi. In: unpublished report by Central Ground Water Board and Central Pollution Control Board, pp 1-209

CGWB (1975) Report on the groundwater exploration in the parts of intermontane Sirsa valley, Nalagarh Teshil, Solan District, Himachal Pradesh Unpub report, pp 1-42. (Unpublished report)

Chadha DK (1999) A proposed new diagram for geochemical classification of natural waters and interpretation of chemical data. Hydrogeol J 7(5):431-439

Collins WD (1923) Graphical representation of water analysis. Int Eng Chem 15:394

CPCB (2007) Guidelines for water quality monitoring, MINARS/27/ 2007-08. http://www.cpcb.nic.in/upload/NewItems/NewItem_ 116_Guidelinesof\%20waterqualitymonitoring_31.07.08.pdf. Accessed 10 June 2017

Dash P, Aggarwal SP, Verma N (2013) Correlation based morphometric analysis to understand drainage basin evolution: a case study of Sirsa river basin, Western Himalayan, India. Sci Anal "Alexandru Ioan Cuza" Univ Iasi 1(2):36-58

Davis SN, Dewiest RJM (1966) Hydrogeology. Wiley, New York, pp $1-463$

Dinkaa MO, Loiskandlb W, Ndambukic JM (2015) Hydrochemical characterization of various surface water and groundwater resources available in Matahara areas, Fantalle Woreda of Oromiya region. J Hydrol Reg Stud 3:444-456

Durfor CN, Becker E (1964) Public water supplies of the 100 largest cities in the United States. In: Geological survey water-supply. US Government Printing Office, Washington, paper no. 1812, p 364

Durov SA (1948) Natural waters and graphic representation of their composition Dokl, Akad. Nauk SSSR 59:87-90

Elango L, Rannan R, Senthil KM (2003) Major ion chemistry and identification of hydrogeochemical processes of groundwater in a part of Kancheepuram district, Tamil Nadu, India. J Environ Geosci 10:157-166

Esakkimuthu K, Kumar KPV, Ponram P (2015) Assessment of waterpollution sources by multivariate statistical methods in Putheri Lake, Kanyakumari, Tamil Nadu, India $\left[08^{\circ} 12^{\prime} 27.1^{\prime \prime} \mathrm{N}\right.$ $\left.77^{\circ} 25^{\prime} 54.7^{\prime \prime} \mathrm{E}\right]$. Sustain. Water Resour. doi:10.1007/s40899015-0031-6

Government of Himachal Pradesh (GoHP) (2011) Economic survey 2010-11. Himachal Pradesh Finance Department, Shimla
Government of India (GoI) (2012) Himachal Pradesh development report, state plan division, planning commission. Government of India, pp 1-18. http://planningcommission.nic.in/plans/stateplan/ sdr_hp/sdr_hpch16.pdf

Guangjia J, Dianwei L, Kaishan S, Zongming W, Bai Z, Yuandong W (2010) Application of multivariate model based on three simulated sensors for water quality variables estimation in Shitoukoumen reservoir, Jilin province, China. Chin Geogr Sci 20(4):337-344

Hamid A, Bhat SA, Bhat SU, Jehangir A (2016) Environmetric techniques in water quality assessment and monitoring: a case study. Environ Earth Sci 75:321

Hammer JM (1986) Water and wastewater technology, 3rd edn. Prentice Hall, New Delhi, pp 63-69, 473-477

Helena B, Pardo R, Vega M, Barrado E, Fernandez JM, Fernandez L (2000) Temporal evolution of groundwater composition in an alluvial aquifer (Pisuerga river, Spain) by principal component analysis. Water Res 34:807-816

Herojeet RK, Rishi M, Tuli N (2013a) Impact of industrialization on groundwater quality: a case study of Nalagarh Valley, Himachal Pradesh, India. Proc Int Conf Integr Water Wastewater Isot Hydrol 3:69-75

Herojeet RK, Rishi SM, Sidhu N (2013b) Hydrochemical characterization, classification and evaluation of groundwater regime in Sirsa watershed, Nalagarh Valley, Himachal Pradesh, India. Civil Environ Res 3(7):47-57

Herojeet RK, Rishi Madhuri S, Sharma R, Lata R (2015a) Hydrochemical characterization, ionic composition and seasonal variation in groundwater regime of an alluvial aquifer in parts of Nalagarh valley, Himachal Pradesh, India. Int J Environ Sci 6(1):68-81

Herojeet RK, Rishi MS, Kishore N (2015b) Integrated approach of heavy metal pollution indices and complexity quantification using chemometric models in the Sirsa Basin, Nalagarh valley, Himachal Pradesh, India. Chin J Geochem 34(4):620-633. doi:10.1007/s11631-015-0075-1

Herojeet RK, Rishi MS, Lata R, Sharma R (2016) Application of environmetrics statistical models and water quality index for groundwater and water quality index for groundwater quality characterization of alluvial aquifer of Nalagarh Valley, Himachal Pradesh, India. Sustain Water Resour Manag 2:39-53

Hickman RE, Gray BJ (2010) Trends in the quality of water in New Jersey streams, water years 1998-2007: US Geological Survey Scientific Investigations. Report 5088:70

Hossain MA, Mir SI, Nasly MA, Wahid ZA, Aziz EA (2012) Assessment of spatial variation of water quality of Tunggak river adjacent to Gebeng industrial estate, Malaysia. Assessment 501(47):A1-07

Isah A, Abdullahi U, Ndamitso MM (2013) Application of multivariate methods for assessment of variations in rivers/streams water quality in Niger State, Nigeria. Am J Theor Appl Stat 2(6):176-183. doi:10.11648/j.ajtas.20130206.14

Iscen CF, Emiroglu O, Iihan S, Arsian N, Yilmaz Ahiska S (2008) Application of multivariate statistical techniques in the assessment of surface water quality in Uluabat Lake, Turkey. Environ Monit Assess 144:269-276

Ismail AH, Abed BSH, Abdul-Qader S (2014) Application of multivariate statistical techniques in the surface water quality assessment of Tigris river at Baghdad stretch, Iraq. J Babylon Univ/Eng Sci 2(22):450-462

Jung KY, Lee KL, Im TH, Lee IJ, Kim S, Han KY, Ahn JM (2016) Evaluation of water quality for the Nakdong River watershed using multivariate analysis. Environ Technol Innov 5:67-82

Kamaldeep, Rishi MS, Kochhar N, Ghosh N (2011) Impact of industrialization on groundwater quality - a case study of Baddi- 
Barotiwala industrial belt, district Solan, Himachal Pradesh, India. J Ind Pollut Cont 27(2):153-159

Kannj I, Achi O (2011) Industrial effluents and their impact on water quality of receiving rivers in Nigeria. J Appl Tech Environ Sanit 1(1):75-86

Khan E (1970) The geology of the area between Chandigarh and Subathu. J Paleontol Soc India 14:47-65

Khan SA (1988) Progress report on systematic hydrogeological surveys in parts of Nalagarh valley area, Solan district, Himachal Pradesh. Central Ground Water Board, Northwestern region, Chandigarh Unpub. Report, pp 1-38. (Unpublished report)

Kim RK, Lee J, Chang HW (2003) Characteristics of organic matter as indicators of pollution from small-scale livestock and nitrate contamination of shallow groundwater in an agricultural area. Hydrol Process 17(12):2485-2496. doi:10.1002/hyp.1256

Kim J, Kim R, Lee J, Cheong T, Yum B, Chang H (2005) Multivariate statistical analysis to identify the major factors governing groundwater quality in the coastal area of Kimje, South Korea. Hydrol Process 19(6):1261-1276. doi:10.1002/ hyp. 5565

Kumar P, Kaushal RK, Nigam AK (2015) Assessment and management of Ganga river water quality using multivariate statistical techniques in India. Asian J Water Environ Pollut 12(4):61-69

Le TTH, Zeunert S, Lorenz M, Meon G (2017) Multivariate statistical assessment of a polluted river under nitrification inhibition in the tropics. Environ Sci Pollut Res. doi:10.1007/s11356-017-8989-2

Lee JY, Cheon JY, Lee KK, Lee SY, Lee MH (2001) Statistical evaluation of geochemical parameter distribution in a ground water system contaminated with petroleum hydrocarbons. J Environ Qual 30:1548-1563

Liu CW, Lin KH, Kuo YM (2003) Application of factor analysis in the assessment of groundwater quality in a Blackfoot disease area in Taiwan. Sci Total Environ 313:77-89

Malik RN, Hashmi MZ (2017) Multivariate statistical techniques for the evaluation of surface water quality of the Himalayan foothills streams, Pakistan. Appl Water Sci. doi:10.1007/s13201-0170532-6

Muangthong S (2015) Assessment of surface water quality using multivariate statistical techniques: a case study of the Nampong river basin, Thailand. J Ind Tech 11(1):25-37

Muangthong S, Shrestha S (2015) Assessment of surface water quality using multivariate ststistical techniques: case study of the Nampong river and Songkhram river, Thailand. Environ Monit Assess 187:548

Noori R, Sadahi MS, Karbassi AR, Baghvand A, Zadeh HT (2010) Multivariate statistical analysis of surface water quality based on correlations and variations in the data set. Desal 260:129-136

Noori R, Karbassi A, Khakpour A, Shahbazbegain M, Badam HMK, Vesali-Naseh M (2012) Chemometric analysis of surface water quality data: case study of the Gorganrud river basin, Iran. Environ Model Assess 17:411-420

Nyamangara J, Jeke N, Rurinda J (2013) Long-term nitrate and phosphate loading of river water in the Upper Manyame catchment, Zimbabwe. Water SA 39(5):637-642. doi:10.4314/ wsa.v39i5.7

Odumosu AOT (1992) Management of liquid industrial wastes. Paper presented at a seminar on Industrial waste management, July 1. Inter match, Lagos, p 6

Okiongbo KS, Douglas RK (2015) Evaluation of major factors influencing the geochemistry of groundwater using graphical and multivariate statistical methods in Yengoa city, Southern Nigeria. Appl Water Sci 5:27-37

Otto M (1998) Multivariate methods. In: Kellner R, Mermet JM, Otto M, Widmer HM (eds) Analytical chemistry. Wiley-VCH, Weinheim, p 916
Papazova P, Simeonova P (2012) Long-term statistical assessment of the water quality of Tundja River. Eco Chem Engg S 19(2):213-226

Papazova P, Simeonova P (2013) Environmetric data interpretation to assess the water quality of Maritsa river catchment. J Environ Sci Health Part A 48(8):963-972

Piper AM (1953) A graphic procedure in the geochemical interpretation of water analysis. US Geol Surv Groundw Note (12):63

Piper AM (1953) A graphic procedure in the geochemical interpretation of water analysis. US Geol Surv Groundw Note 12

Pires JCM, Pereira MC, Alvim-Ferraz MCM, Martins FG (2009) Identification of redundant air quality measurements through the use of principal component analysis. Atmos Environ 43:3837-3842

Qadir A, Malik RN, Husain SZ (2008) Spatio-temporal variations in water quality of Nullah Aik-tributary of the river Chenab, Pakistan. Environ Monit Assess 140:43-59

Ravikumar P, Somashekar RK (2015) Principal component analysis and hydrochemical facies characterization to evaluate groundwater quality in Varahi river basin. Appl Water Sci, Karnataka state. doi:10.1007/s13201-015-0287-x

Razmkhah H, Abrishamchi A, Torkian A (2010) Evaluation of spatial and temporal variation in water quality by pattern recognition techniques: a case study on Jajrood River (Tehran, Iran). J Environ Manag 91:852-860

Reghunath R, Murthy TRS, Raghavan BR (2002) The utility of multivariate statistical techniques in hydrogeochemical studies: an example from Karnataka, India. Water Res 36:2437-2442

Reza R, Singh G (2010) Assessment of heavy metal contamination and its indexing approach for river water. Int J Environ Sci Tech 7(4):785-792

Shrestha S, Kazama F (2007) Assessment of surface water quality using multivariate statistical techniques: a case study of the Fuji river basin, Japan. Environ Model Soft 22:464-475

Sidhu N, Rishi SM, Herojeet RK (2013) Groundwater quality variation with respect to aquifer dispositioning in urbanized watershed of Chandigarh, India. IJEEFUS 3(2):87-98

Simeonov VJ, Stratis CJ, Samara GJ, Zachariadis D, Voutsa A, Anthemidis M, Sofriniou T, Koumtzis T (2003) Assessment of the surface water quality in Northern Greece. Water Res 37(17):4119-4124

Simeonov V, Simeonova P, Tsitouridou R (2004) Chemometric quality assessment of surface waters: two case studies. Eco Chem Eng 11(6):449-469

Singh KP, Malik A, Mohan D, Sinha S (2004) Multivariate statistical techniques for the evaluation of spatial and temporal variations in water quality of Gomti River (India): a case study. Water Res 38:3980-3992

Singh KP, Malik A, Sinha S (2005) Water quality assessment and apportionment of pollution sources of Gomti river (India) using multivariate statistical techniques: a case study. Anal Chim Acta 538:355-374

Singh KP, Gupta S, Rai P (2014) Investigating hydrochemistry of groundwater in Indo-Gangetic alluvial plain using multivariate chemometric approaches. Environ Sci Pollut Res 21:6001-6015

Srivastava SK, Ramanathan AL (2008) Geochemical assessment of groundwater quality in vicinity of Bhalswa landfill, Delhi, India, using graphical and multivariate statistical methods. Environ Geol 53:1509-1528

Sum L, Gui H (2015) Hydro-chemical evolution of groundwater and mixing between aquifers: a statistical approach based on major ions. Appl Water Sci 5:97-104

Swanson S, Bahr J, Schwar M, Potter K (2001) Two-way cluster analysis of geochemical data to constrain spring source waters. Chem Geol 179:73-91 
Tay CK (2012) Hydrochemistry of groundwater in the SaveluguNanton District, Northern Ghana. Environ Earth Sci 67:2077-2087

Todd DK (1980) Groundwater hydrology, 2nd edn. Wiley, New York, pp $1-535$

Todd DK, Mays LW (2005) Groundwater hydrology. Wiley, New York, pp 1-636

UNEP (2000) Global environment outlook-2000. Earthscan, London

Vega M, Pardo R, Barrado E, Deban L (1998) Assessment of seasonal and polluting effects on the qualityof river water by exploratory data analysis. Water Res 32:3581-3592

Vieira JS, Pires JCM, Martins FG, Vilar VJP, Boaventura RAR, Botelho CMS (2012) Surface water quality assessment of Lis River using multivariate statistical methods. Water Air Soil Pollut. doi:10.1007/s11270-012-1267-5

Vipan KV, Raj KS, Mohinder PSK (2013) Ugly face of urbanization and industrialization: a study of water pollution in Buddha nala of Ludhiana city, India. J Environ Conserv Res 1(1):6-11

Wai WW, Alkarkhi AFM, Azhar ME (2010) Comparing biosorbent ability of modified citrus and durian rind pectin. Carbohydr Polym 79(3):584-589
Walton WC (1970) Classification and use of irrigation waters. US Department of Agriculture, Circular no. 969, p 19

Wang Y, Wang P, Bai Y, Tian Z, Li J, Shao X, Mustavich LF, Li BL (2013) Assessment of surface water via multivariate statistical techniques: a case study of the Songhua river Harbin region, China. J Hydro-environ Res 7:30-40

WHO (1993) Guidelines for drinking water quality, vol 1, 2nd edn. Recommendations, Geneva, p 13

WHO (2011) WHO guidelines for drinking water quality, 4th edn. World Health Organisation, Geneva, pp 1-564

Wunderlin DA, Diaz MP, Ame MV, Pesce SF, Hued AC, Bistoni MA (2001) Pattern recognition techniques for the evaluation of spatial and temporal variations in water quality. A case study: Suquia river basin (Cordoba, Argentina). Water Res 35:2881-2894

Yisa J, Jimoh T (2010) Analytical studies on water quality index of river Landzu. Am J Appl Sci 7(4):453-458

Zhao Y, Xia XH, Yang ZF, Wang F (2012) Assessment of water quality in Baiyangdian Lake using multivariate statistical techniques. Proc Environ Sci 8:1240-1253. doi:10.1016/j. proenv.2012.01.115 